NASA Technical Memorandum 100104

AIAA-87-1773

\title{
An Evaluation of Metallized Propellants Based on Vehicle Performance
}

Robert L. Zurawski

Lewis Research Center

Cleveland, Ohio

and

James M. Green

Sverdrup Technology, Inc.

Lewis Research Center

Cleveland, Ohio -

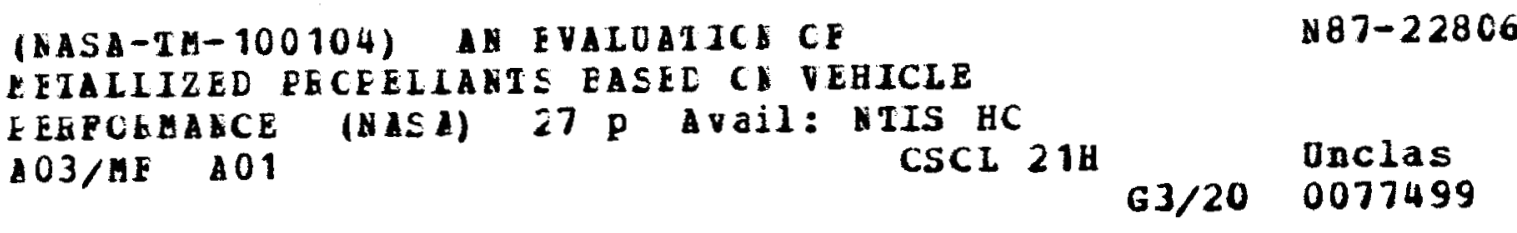

Prepared for the 23rd Joint Propulsion Conference cosponsored by the AIAA, SAE, ASME, and ASEE San Diego, California, June 29-July 2, 1987 
AN EVALUATION OF METALIIIZE PROPELLANTS BASED ON VEHICLE PERFORMANCE

\author{
Robert L. Zurawski \\ National Aeronautics and Space Administration \\ Lewis Research Center \\ Cleveland, Ohio 44135
}

and

James M. Green

Sverdrup Technology, Inc.

Lewis Research Center

Cleveland, Ohio 44135

\title{
SUMMARY
}

An analytical study was conducted to determine the improvements in vehicle performance possible by burning metals with conventional liquid bipropellants. These metallized propellants theoretically offer higher specific impulse, increased propellant density and improved vehicle performance compared with conventional liquid bipropellants. Metals considered were beryllium, lithium,

$\stackrel{c}{\%}$ aluminum and iron. Liquid bipropellants were $\mathrm{H}_{2} / \mathrm{O}_{2}, \mathrm{~N}_{2} \mathrm{H}_{4} / \mathrm{N}_{2} \mathrm{O}_{4}, \mathrm{RP}-1 / \mathrm{O}_{2}$ and $\mathrm{H}_{2} / \mathrm{F}_{2}$. A mission with $\Delta V=4267.2 \mathrm{~m} / \mathrm{sec}(14000 \mathrm{ft} / \mathrm{sec}$ ) and vehicle with propellant volume fixed at $56.63 \mathrm{~m}^{3}\left(2000 \mathrm{ft}^{3}\right)$ and dry mass fixed at $2761.6 \mathrm{~kg}$ (6000 lb) was used, roughiy representing the transfer of a chemically propelled, upper-stage vehicle from a low Earth orbit to a geosynchronous orbit. The results of thermochemical calculations and mission analysis calculations for liquid bipropellants metallized with beryllium, lithium, aluminum and iron are presented. Technology issues pertinent to metallized propellants are discussed.

\section{INTRODUCTION}

The selection of rocket propellants for a particular application depends on many factors including performance, cost, and safety. A number of steps are involved in analytically evaluating the potential of a rocket propellant combination. The first step is to determine rocket engine performance based on specific impulse. Thermochemical calculations are conducted to identify peak specific impulse for the engine configuration to be used in the application. Peak values can be compared for various propellant combinations to determine which yields the optimal propulsion system performance. However, propulsion system performance alone is insufficient to make a propellant selection. Vehicle performance parameters such as the velocity change of the vehicle or the quantity of payload that can be delivered in a mission must next be calculated. Flight relation equations are used in which both the density and specific impulse of the propellant combination become important. In this process, physical constraints resulting from the requirements of the application must be considered. Finally, in evaluating rocket propellants for a particular application, the potential benefits in vehicle performance must be weighed against safety, cost, and technical considerations. The potential benefits derived from an advanced rocket propellant are inconsequential if 
safety requirements for the application cannot be satisfied, cost for develop ment or operation are unrealistically large, or if the required technology cannot be developed.

This report presents the results of an evaluation of metallized propellants. Propulsion system performance (specific impulse) and vehicle performance (delivered payload mass) are emphasized in the evaluation, although safety and technology issues are also discussed. Thermochemical calculations were conducted to identify the specific impulse of several metallized propellant combinations over a range of compositions. Propellant density data were then calculated as a function of propellant composition. Finally, a simplified upper-stage mission was chosen, and flight performance parameters were calculated using the propulsion system performance and propellant density data.

Metallized propellant (tripropellant) systems consist of a liquid fuel, a liquid oxidizer, and a metal fuel. The metal is typically suspended in fine particulate form as a slurry or gel in the fuel, oxidizer, or a separate carrier fluid, although any metal management system allowing good combustion efficiency could be considered. These metallized propellants have several potential advantages over conventional liquid bipropellants and offer the opportunity to advance chemical rocket propulsion performance beyond that of any liquid bipropellant. The most important of these advantages is the possibility for improved specific impulse and propellant density compared to conventional bipropellant combinations. Better vehicle performance is the end result of these improvements. Other advantages may stem from the use of metallized propellants depending upon the state of the propellant. For example, gelling the metal in the liquid propellant could lead to better storage and handiing properties. Since gels are semisolid in composition, mechanical or hydrostatic propellant delivery systems could be used. The need for baffles in propellant tanks may be eliminated, thus reducing vehicle dry mass. Evaporation of cryogenic propellants may be reduced, thereby simplifying ground processing procedures. Finally, an increased margin of safety may be possible due to the flow resistance of the gelled propellant to leaks in tanks and propellant lines.

Metallized propellants are not new to rocket propulsion. Early analytical work in the 1960's generated interest in low molecular weight, high energy metals such as beryllium and lithium. Aluminum was also investigated because of its good combustion energy and desirable density. Experimental demonstrations followed which were primarily directed toward ballistic applications. However, the concept was eventually abandoned after significant technical efforts as budgets for high-risk, high-payoff propulsion technology began to diminish. The major problems remaining unsolved at that time included; combustion inefficiencies and two-phase flow losses limiting delivered performance, safety problems with propellants like beryllium, and the inability to develop an effective metal storage, transport, and injection system. A more detalled review of the history of metallized propellants is contained in reference 1 .

Metallized propellants still offer the potential for state-of-the-art advancements in chemical rocket propulsion performance and are reexamined here with today's improved computational capabilities in light of current applications and technology. Metals considered in the analysis were beryllium (Be), lithium ( $L i)$, aluminum $(A l)$ and iron ( $F e)$. Bipropellant systems considered were hydrogen/oxygen $\left(\mathrm{H}_{2} / \mathrm{O}_{2}\right)$, hydrogen/fluorine $\left(\mathrm{H}_{2} / \mathrm{F}_{2}\right)$, hydrazine/nitrogen 
tetroxide $\left(\mathrm{N}_{2} \mathrm{H}_{4} / \mathrm{N}_{2} \mathrm{O}_{4}\right)$, and RP-1/oxygen (RP-1/02). Iron was included because of its good combustion energy and very high density. The other metals, although considered in the past, are reexamined here with a wide variety of liquid bipropellant systems. Whereas past work focused heavily on specific impulse for improvements in vehicle performance, the importance of both speci. fic impulse and propellant density are considered here.

\section{THERMOCHEMICAL CALCULATIONS}

Specific impulse advantages of metallized tripropellants over conventional liquid bipropellants result because of the large amount of energy released when the metal component burns. If we assume any condensed phases to be in velocity equilibrium with the gaseous phase, the following equation can be used to calculate specific impulse:

$$
I_{s p}=\frac{\sqrt{2 g_{0} J\left(H_{c}-H_{e}\right)}}{g_{0}}
$$

Since the enthalpy change is the heat release per unit weight of material,

$$
I_{s p} \propto \sqrt{\frac{T_{c}}{M_{c}}}
$$

Therefore, specific impulse is roughly proportional to the square root of the ratio of chamber temperature to molecular weight. Specific impulse is increased by elevating the energy of the system and reducing the molecular weight of the combustion products. Metallized propellants can supply the optimum combination of a high-energy source and low molecular weight, which accounts for their increased specific impulses.

Figure 1 shows the combustion energies of some of the elements when added to oxygen and fluorine. Notice the decaying sinusoidal nature of the combustion energy with atomic number. This trend continues beyond an atomic number of 18. Based on combustion energy, the elements that appear most attractive for use in metallized propellant combinations include beryllium, lithium, boron, magnesium, and aluminum. Beryllium, lithium, and boron appear particularly attractive for improving specific impulse because of their high combus. tion energy and low molecular weight. Since aluminum and magnesium have higher molecular weights, the addition of these metals to liquid bipropellants would not be expected to improve specific impulse as much as berylitum, lithium, or boron. Iron is not shown in figure 1 because it has an atomic number of 26 . The combustion energy of iron with oxygen is $5320 \mathrm{~J} / \mathrm{g}(2290 \mathrm{Btu} / \mathrm{lb})$. Consideration of propellant density may provide justification for using heavier elements such as iron as metal rocket propellant additives. Table I contains element property data such as specific gravity and molecular weight for selected elements. The high density of aluminum and iron relative to the other elements is evident. Since vehicle performance depends on both specific impulse and propellant density, the high density of aluminum and iron is a desirable characteristic of these metals when they are used as rocket propellants. 
In order to assess the potential of these metals as rocket propellants, thermochemical calculations were first conducted to identify specific impulse. Gordon and McBride's Computer Program for Calculation of Complex Equilibrium Compositions, Rocket Performance, Incident and Reflected Shocks, and Chapman. Jouguet Detonations (CEC computer program) (ref. 2) was used to generate vacuum specific impulse values for the metallized propellant combinations over a wide range of mixture ratios and metal loadings. Mixture ratio is defined for metallized propellant combinations as the ratio of liquid oxidizer mass to the sum of liquid-fuel mass and metal mass. Metal loading is defined as the weight percentage of the total fuel (metal plus liquid fuel) that is metal fuel. The program generated the theoretical rocket parameters by assuming shifting equilibrium, ideal expansion to a vacuum from a $6.895-\mathrm{MN} / \mathrm{m}^{2}$ ( $\left.1000 \mathrm{psia}\right)$ chamber pressure. A rocket nozzle with a $60: 1$ area ratio (ratio of the nozzle exit area to throat area) was assumed.

The results of the thermochemical calculations are shown in figures 2 to 5 which plot vacuum specific impulse versus metal loading for each of the metals and liquid bipropellants considered in the analysis. Figure 2 shows how beryllium, with is high combustion energy and low molecular weight, can increase the specific impulse of each liquid bipropeliant combination. This improvement in rocket performance is most striking with the $\mathrm{Be} / \mathrm{H}_{2} / \mathrm{O}_{2}$ tripropellant which offers the highest specific impulse of any chemical propellant combination. The improvements in specific impulse are not as pronounced with the storable and hydrocarbon bipropellants because thermal energy is not as easily converted to kinetic energy with the higher molecular weight exhaust products. Figure 3 shows the rocket performance of each liquid bipropellant with lithium addition. The performance of the $\mathrm{H}_{2} / \mathrm{F} 2, \mathrm{H}_{2} / \mathrm{O}_{2}$ and $\mathrm{N}_{2} \mathrm{H}_{4} / \mathrm{N}_{2} \mathrm{O}_{4}$ bipropellants benefit from the addition of lithium. Lithium produces thermally stable fluorides which do not dissociate at high combustion temperatures. This accounts for the good specific impulse of $\mathrm{Li} / \mathrm{H}_{2} / \mathrm{F}_{2}$. The dissociation of lithium oxide at high temperatures is the source of lithium's moderate performance with the $\mathrm{H}_{2} / \mathrm{O}_{2}$ system. Figure 4 illustrates how aluminum addition affects the specific impulse of various liquid bipropellants. Slight improvements in theoretical rocket performance are possible by the addition of aluminum to the $\mathrm{H}_{2} / \mathrm{O}_{2}$ and $\mathrm{N}_{2} \mathrm{H}_{4} / \mathrm{N}_{2} \mathrm{O}_{4}$ bipropellants. Although aluminum is an energetic metal, it has a high molecular weight which is not conducive to high specific impulse. Finally, the rocket performance of iron is shown in figure 5. Iron addition to liquid bipropellants decreases theoretical specific impulse because of its high molecular weight and low combustion energy relative to the other metals. However, the potential of high density metals like aluminum and iron can only be determined by considering both specific impulse and propellant density in calculating flight performance parameters. This was the subject of further analysis which is presented in the Mission Analysis section of this report.

Peak theoretical vacuum specific impulse, mixture ratio and metal loading for each of the metallized propellants are presented in table II. Peak rocket performance is also presented graphically in figure 6 . Certain metals, when added to a particular bipropellant, do not increase specific impulse. Zero percent metal addition is indicated in figure 6 for these cases. It must also be noted that the specific impulse physically achievable from metallized propellant combinations will be less than theoretical after taking into account realistic losses due to combustion inefficiencies, chemical kinetic effects, 
two-phase flow, nozzle divergence, wall friction, and nozzle back-pressure. An analytical prediction of these losses was beyond the scope of this analysis.

Based on theoretical rocket performance (specific impulse), beryllium and lithium appear very promising as rocket propellants while aluminum and iron do not. However, the ultimate criteria of the performance of a rocket propellant are flight parameters (such as payload mass or $\Delta V$ ) which reflect the effects of both specific impulse and propellant density. Therefore, mission analysis must be conducted to determine the true potential of high density, low energy metals such as aluminum and iron or low density, high energy metals such as beryllium and lithium. In addition, safety, cost and technology issues must be considered. The potential of a rocket propellant cannot be judged solely on specific impulse.

\section{MISSION ANALYSIS}

The relative importance of specific impulse and propellant density can be seen in the following rocket equation, which (assuming aerodynamic and drag forces to be negligible) gives the change in velocity of a rocket powered vehicle:

$$
\Delta V=g_{0} I_{s p} \ln \frac{M_{0}}{M_{f}}=g_{0} I_{s p} \ln \frac{M_{p}+M_{d}+M_{p l}}{M_{d}+M_{p l}}
$$

Since propellant mass is the product of bulk propellant density $\rho_{p}$ and total tankage volume for all propellant $v_{p}$, the rocket equation becomes

$$
\Delta V=g_{0} I_{s p} \ln \frac{M_{0}}{M_{f}}=g_{0} I_{s p} \ln \frac{\rho_{p} V_{p}+M_{d}+M_{p l}}{M_{d}+M_{p l}}
$$

Rearranging the equation yields

$$
M_{p 1}=\frac{\rho_{p} V_{p}}{e^{\left(\Delta V / g_{0} I s p\right)}-1}-M_{d}
$$

This equation shows that payload capability is directly proportional to propellant density. Figure 7 shows the effect of bulk propellant density on payload mass. This figure was plotted from equation (5) by varying bulk propellant density from $200.0 \mathrm{~kg} / \mathrm{m}^{3}\left(12.49 \mathrm{lb} / \mathrm{ft}^{3}\right)$ to $1600.0 \mathrm{~kg} / \mathrm{m}^{3}\left(99.88 \mathrm{lb} / \mathrm{ft}^{3}\right)$ and specific impulse from 250 to $450 \mathrm{sec}$ with $\Delta V=4267.2 \mathrm{~m} / \mathrm{sec}$ $(14,000 \mathrm{ft} / \mathrm{sec}), V p=56.63 \mathrm{~m}^{3}\left(2000 \mathrm{ft}^{3}\right)$, and $M_{d}=2721.6 \mathrm{~kg}(6000 \mathrm{lb})$. This roughly represents the transfer of a chemically propelled, upper-stage vehicle from a low Earth orbit to a geosynchronous orbit. The figure shows that payload capability increases with density along lines of constant specific impulse. However, in reality, payload mass does not directly increase with either parameter because of the thermochemical relationship between propellant specific impulse and bulk propellant density (i.e., mixture ratio and metal loading). The curve for $\mathrm{A} 1 / \mathrm{H}_{2} / \mathrm{O}_{2}$ payload capability illustrates this.

This curve was calculated from specific impulse, mixture ratio, and metal loading data. The bulk density of the propellant combination is a value of a 
hypothetical mixture of liquid oxidizer, liquid fuel, and metal fuel and gives an indication of the compactness of the propellant combination. Bulk propellant density was calculated from the following equation which is derived in reference 1 .

$$
\rho_{p}=\frac{(1+M R)}{\frac{M R}{\rho_{o x}}+\frac{(1-M L)}{\rho_{f}}+\frac{M L}{\rho_{m}}}
$$

The payload capability curve for $\mathrm{Al} / \mathrm{H}_{2} / \mathrm{O}_{2}$ ( $\mathrm{fig} .7$ ) shows that payload mass increases with bulk propellant density, in spite of the decrease in specific impulse. Therefore, for a given mission and venicle (i.e., fixed dry mass, propellant volume, and velocity change), increasing bulk propellant density with high-density metals can lead to payload advantages. Conversely, the addition of low density metals to liquid bipropellants could conceivably reduce payload capability while improving rocket performance (specific impulse). It is important to realize that the potential of a rocket propellant is ultimately judged on vehicle performance which is a function of both specific impulse and propellant density. A number of references are available which discuss the relative importance of specific impulse and propellant density for rocketpowered vehicles (refs. 3 and 4 ).

In order to assess the potential of metallized propellant combinations, mission analyses considering the combined impact of specific impulse and propellant density were conducted. Since the objective of the analys is was to compare the performance of one metallized propellant combination to another and to the unmetallized liquid bipropellants, a simplified mission was assumed. A mission with $\Delta V=4276.2 \mathrm{~m} / \mathrm{sec}(14000 \mathrm{ft} / \mathrm{sec})$ and vehicle with propellant volume fixed at $56.63 \mathrm{~m}^{3}\left(2000 \mathrm{ft}^{3}\right)$ and dry mass fixed at $2761.6 \mathrm{~kg}$ (6000 ib) was selected. This roughly represents the transfer of a chemically propelled, upper-stage vehicle from a low Earth orbit to a geosynchronous orbit. The vehicle is propelled by a rocket operating at $6.895-\mathrm{MN} / \mathrm{m}^{2}$ (1000 psia) chamber pressure with a $60: 1$ area ratio nozzle.

The assumptions of fixed propellant volume, constant dry mass and mission $\Delta V$ are permissible for the purpose of comparing propellant performance in certain applications. A fixed envelope volume is often a requirement of an application. For example, an upper-stage vehicle could be volume constrained by the payload bay of the space shuttle. The replacement of final destination by $\Delta V$ is a permissible simplification if velocity losses such as drag are negligible or independant of the propellants used. For missions where large drag losses are inherent, significant $\Delta V$ changes may occur due to vehicle drag area changes resulting from variations in propellant density. This is not the case for upper-stage missions. Finaliy, vehicle dry mass (tank masses, miscellaneous hardware, engine mass, etc.) can be considered constant if optimum propulsion system operating conditions (chamber pressure, tank pressure, etc.) are not a strong function of propellant density (ref. 3).

Several flight performance parameters such as delivered payload mass, minimum weight, occupancy of minimum volume for a given mission, or the velocity change for a given vehicle can be used to quantify vehicle performance. Delivered payload mass was taken as a measure of performance for this analysis. Payload mass was calculated from equation (5) using the theoretical vacuum specific impulse data. Bulk propellant density was calculated for each mixture ratio and metal loading using equation $(6)$. 
The results of the mission analysis are shown in figures 8 to 14 which plot delivered payload mass versus metal loading for each of the metals and liquid bipropellant systems considered in the analysis. Figure 8 shows the payload capability of beryllium with $\mathrm{H}_{2} / \mathrm{O}_{2}$, RP-1/02, and $\mathrm{N}_{2} \mathrm{H}_{4} / \mathrm{N}_{2} \mathrm{O}_{4}$.

Beryllium addition improves the performance of all three bipropellants, with the more dense liquid bipropellant systems delivering higher absolute payload masses in the fixed-volume application. The improvement in vehicle performance by beryllium addition is most pronounced with the $\mathrm{N}_{2} \mathrm{H}_{4} / \mathrm{N}_{2} \mathrm{O}_{4}$ system. Beryllium has high combustion energy, low molecular weight, and high density which ultimately leads to these improvements in flight performance. Figure 9 shows the payload capability of lithium with the liquid bipropellants. Lithium addition results in improved vehicle performance only with $\mathrm{H}_{2} / \mathrm{F}_{2}$ and $\mathrm{H}_{2} / \mathrm{O}_{2}$ bipropellants because of the low density of lithium and because specific impulse improvements are appreciable only with these bipropellants. However, the improvements in vehicle performance are slight. The improvements in payload capability theoretically possible by the addition of aluminum to the liquid bipropellants are shown in figure 10. Increased performance in the $\mathrm{N}_{2} \mathrm{H}_{4} / \mathrm{N}_{2} \mathrm{O}_{4}$ system is due to a combination of improved specific impulse and increased propellant density. In the RP- $1 / \mathrm{O}_{2}$ and $\mathrm{H}_{2} / \mathrm{O}_{2}$ systems, increased paylaad mass is attributed almost entirely to increased propellant density by addition of aluminum. As shown in figure 17 , the addition of iron to conventional liquid bipropellants shows no potential for increasing performance with the assumed mission model. Although iron has a very high density, the degradation in specific impulse by iron addition to the liquid bipropellants is too severe.

Figures 12 to 14 compare the vehicle performance of the metals with each liquid bipropellant combination. Aluminum and beryllium are the only metals which show real promise for improving performance of the $\mathrm{H}_{2} / \mathrm{O}_{2}, \mathrm{~N}_{2} \mathrm{H}_{4} / \mathrm{N}_{2} \mathrm{O}_{4}$, and RP- $1 / \mathrm{O}_{2}$ bipropellants. Lithium has a high combustion energy but low density. Iron has high density but low combustion energy. Aluminum and beryllium posses the proper balance of combustion energy and density to deliver improved theoretical flight performance.

Peak vehicle performance for all propellant combinations analyzed are presented in table III with the corresponding rocket performance (vacuum specific impulse, mixture ratio and metal loading) and propellant density. Detailed tables of theoretical flight performance (delivered payload mass) as a function of rocket performance and propellant density are presented for each metallized propellant combination in tables IV to XVI. Peak vehicle performance is also presented graphically in figure 15. Certain metals, when added to a particular bipropellant, do not enhance performance. Zero percent metal addition is depicted in figure 15 for these cases. An alternate method for comparing the performance of propellant systems is presented in appendix $B$. The performance of the metallized propeliant and bipropellant combinations is compared in figure 16 using the parameter presented in appendix $B$.

\section{TECHNICAL DISCUSSION}

After a propellant combination has been evaluated based on rocket and flight performance parameters, safety and technical issues associated with the use of the propellant combination must be considered. Theoretical analysis of rocket and flight parameters indicates that metaliized propeliants potentially offer significant performance advantages over their corresponding biprope 1lants. However, because of the energetic nature of the propellants and the 
presence of the solid metal in the system, an advanced technology is required to develop a reliable, high-energy propulsion system using metallized propel. lants. Safety concerns also arise with the use of some metallized propellant combinations. This discussion is concerned with some major technical and safety issues associated with metallized propellants. More detailed discussion is contained in reference 1 .

Safety is a primary consideration when selecting a rocket propellant for any application. Several of the metallized propellant combinations discussed here do present safety problems. Beryllium shows good potential for increasing the performance of certain liquid bipropellants. However, the toxicity of beryllium and its derivatives remains an important aspect to consider. The toxicity of berylium metal has prevented its past use with solid and liquid propellant rocket systems and is a deterrent to its future use as a rocket propellant. Propeliant combinations using fluorine as the oxidizer also present unique safety hazards. The unusually high density of fluorine, coupled with the favorable propellant mixture ratios inherent in the stoichiometry of its combustion, make fluorine a high-performing oxidizer. However, the potential problems in handing fluorine tend to discourage its consideration for rocket propulsion systems (ref. 5). Potential safety hazards do exist with some of the other propellants discussed here such as hydrazine, nitrogen tetroxide, and liquid hydrogen, but these hazards can be controlled so that such propellants are routinely used in current rocket propulsion applications.

Several technology areas are of major importance in evaluating the potential of metallized propellants. These technologies include metal ignition and combustion, performance losses, thrust chamber cooling, advanced materials, and the storage, transport, and injection of the metal. A metallized propel. lant propulsion system must be designed for high performance. Rocket performance losses due to inefficient combustion and two-phase flow could negate the flight performance advantages theoretically possible with metallized propellant combinations. Efficient combustion of the metal in metallized propellants requires small, solid particles, large residence times for the reactants in the thrust chamber, and a core temperature in the thrust chamber high enough to initiate and maintain combustion of the metal. The development of an effective metal management system and an effective thrust chamber configuration is the first step toward ensuring good combustion efficiency with metallized propellants.

The combustion of metals in metallized propellant combinations results in the formation of small metal-oxide particles whose thermal energy must be converted to kinetic energy by heat and momentum exchange with the surrounding gas in the nozzle. A decreased nozzle efficiency results if the solid fails to maintain thermal and velocity equilibrium with the gas. To prevent such two-phase flow losses, the solid particles must be kept very small so that they will have the same velocity as the gas and be in thermal equilibrium with the gas. Heat transfer will also be greater in metallized propellant thrust chambers than in chambers using conventional propellants because of the presence of the particulate matter in the combustion gases. Advanced cooling techniques would be required to adjust for the increased heat transfer in these rockets. In addition the impingement of solid metal particles on the thrust chamber wall could create durability problems in reusable propulsion systems necessitating development of advanced thrust chamber materials. 
Finally, an effective metal management system must be developed for the storage, transport, and injection of the metal. Several types of systems have been explored in the past. The most popular technique has been to suspend the metal in fine particulate form in the liquid fuel as a slurry or gel. In this way the metal could be transported and injected along with the liquid fuel. However, many technical challenges are associated with developing a reliable gelled, metalijzed fuel combination. Potential problems exist in areas including storage stability, abrasion and clogging of propulsion system components, and propellant waste due to residual deposits in tanks and propellant lines. The concept of metallizing liquid bipropellants is a novel approach for improving performance, but an advanced technology is required to make it practical and safe.

\section{CONCLUDING REMARKS}

State-of-the-art advancements in chemical rocket propulsion have historically been driven by the energetics of the propellant. Metallized propellants offer the opportunity to advance the state-of-the-art in chemical rocket performance because they are more energetic than conventional propeliants. The addition of metals to conventional liquid bipropellants shows promise for increasing specific impulse or propellant density or both depending on the type and amount of metal added.

It is important to consider propulsion system performance, fiight performance, and safety and technology issues when evaluating the potential of a propellant combination for a particular application. Thermochemical calculations were conducted to determine the specific impulse advantages of metallized propellant combinations compared to unmetallized liquid bipropellants. The addition of low molecular weight, high-energy metals like beryllium and lithium to liquid bipropellants can significantly increase rocket performance. High density metals like aluminum and iron with lower combustion energies yield little or no specific impulse improvements. However, the ultimate criteria of the performance of a rocket propellant are flight parameters which reflect the effects of both specific impulse and propellant density. Simplified upperstage mission analyses were conducted to assess the potential of metallized propellant systems based on flight performance. Iron shows no potential for increasing performance when added to liquid bipropellants. Aluminum and beryllium both appear attractive for improving flight performance when added to liquid bipropellants because of increased specific impulse and propellant density.

Safety and technology issues were reviewed as a final step in evaluating the potential of metallized propellant combinations since benefits in perform ance are inconsequential if safety requirements for the application cannot be satisfied or if the required technology cannot be developed. Safety (toxicity) problems discourage the use of beryllium as a rocket propeliant. Lithium shows potential for increasing the performance of the $\mathrm{H}_{2} / \mathrm{F}_{2}$ bipropellant, but fluorine exhibits unique safety hazards. Aluminum is the only metal examined in this analysis that shows potential for improving rocket and fiight performance and also presents no unique safety problems. Future work on metallized propellant systems should focus on technologies associated with the addition of aluminum to liquid bipropellant systems. 
Metallized rocket propellants show promise based on the theoretical analysis of this report, but future experimental efforts are needed to further explore these propeliants and realistically evaluate their advantages. Technologies which need to be immediately addressed include physical and chemical properties of metallized propellants, metal ignition and combustion phenomena, performance losses due to two-phase flow and combustion inefficiencies, cooling requirements, advanced thrust chamber materials, and the storage, transport, and injection of the metal. The concept of metallizing liquid bipropellant systems shows promise for increasing rocket propellant performance, but an advanced technology is required to make the concept feasible. 
SYMBOLS

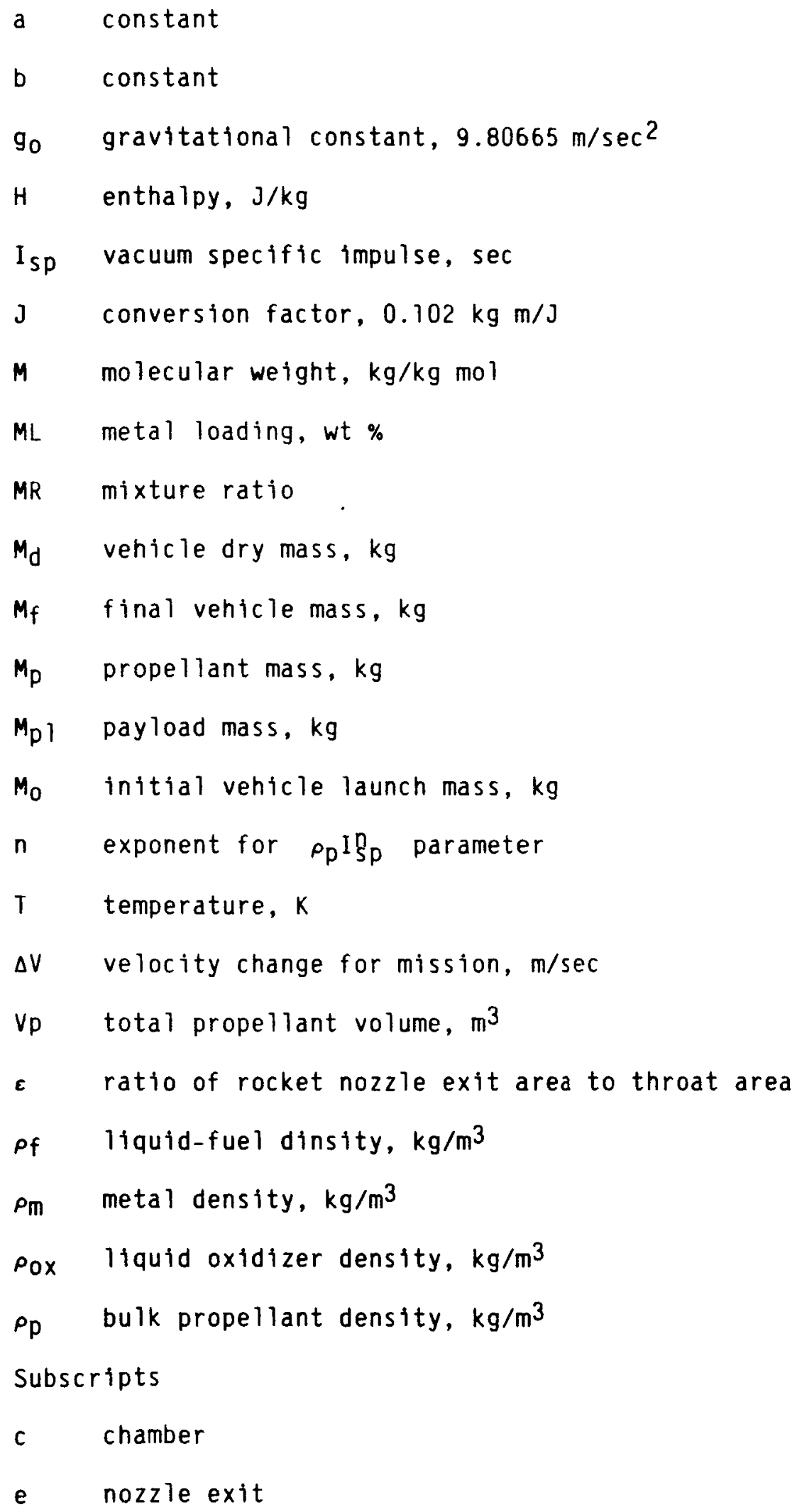




\section{EFFECT OF PROPELLANT DENSITY AND SPECIFIC IMPULSE ON FLIGHT PERFORMANCE}

As iliustrated by the analysis of this report, the determination of propellant performance is a time consuming and complicated process which must be repeated for each application and propellant combination. A convenient method of determining the potential of rocket propellant combinations without performing this lengthy process is therefore desirable. Since both specific impulse and propellant density are significant in the evaluation of rocket propellant performance, a parameter including both variables could be used as a preliminary criterion for the evaluation of the performance of rocket propellant combinations. Such a parameter can be derived from the rocket equation (eq. (5)). By expanding the exponential term in the rocket equation using an infinite series expansion, the following linear relationship between delivered payload mass and $\rho_{p}{ }_{s p}^{n}$ can be shown where $a$ and $b$ are constants, and the exponent $n$ depends on the vehicle and mission.

$$
M_{p 1}=\frac{\rho_{p} V_{p}}{e^{\left(\Delta V / g_{0} I_{S p}\right)}-1}-M_{d r y} \alpha a\left(\rho_{p} I_{S p}^{n}\right)+b
$$

$n$ correlates well with the mission $\Delta V$. For the upper-stage vehicle and mission considered in this analysis, $n$ is approximately 2 . Therefore, the highest performing propellant combination for this application yields the greatest value of $\rho_{p} I_{s p}^{2}$. The relative performance of the propellant combinations considered in this analysis can be seen in figure 16 which plots delivered payload mass versus $\rho_{p} I_{s p}^{2}$. The linear relationship between delivered payload mass and $\rho_{p} I_{s p}^{2}$ is evident. 


\section{REFERENCES}

1. Zurawski, R.L., "Current Evaluation of the Tripropellant Concept," NASA TP-2602, 1986.

2. Gordon, S. and MCBride, B.J., "Computer Program for Calculation of Complex Chemical Equilibrium Compositions, Rocket Performance, Incident and Reflected Shocks, and Chapman-Jouquet Detonation," NASA SP-273, 1971.

3. Jortner, J., "Comparative Applicabllity of Storable Propellants: Effects of Specific Impulse and Density," Liquid Rockets and Propellants, L.E. Bollinger, M. Goldsmith, and A.W. Lemmon, eds., Academic Press, New York, 1960, pp. 471-493.

4. Meliish, J.A. and Gibb, J.A., "Liquid Propellant Comparison Based on Vehicle Performance," Liquid Rockets and Propellants, L.E. Bollinger, M. Goldsmith, and A.W. Lemmon, eds., Academic Press, New York, 1960, pp. 447-470.

5. Schmidt, H.W. and Harper, J.T., "Handling and Use of Fluorine and Fluorine oxygen Mixtures in Rocket Systems," NASA SP-3037, 1967.

6. Sarner, S.F., Propellant Chemistry, Reinhold, New York, 1966.

TABLE I. - PROPERTY DATA FOR SELECTED ELEMENTS

\begin{tabular}{|l|c|c|c|c|c|c|}
\hline Name & Symbol & $\begin{array}{l}\text { Atomic } \\
\text { number }\end{array}$ & $\begin{array}{l}\text { Molecular } \\
\text { weight }\end{array}$ & $\begin{array}{l}\text { Melting } \\
\text { point, } \\
{ }^{\circ} \mathrm{C}\end{array}$ & $\begin{array}{l}\text { Boiling } \\
\text { point, } \\
{ }^{\circ} \mathrm{C}\end{array}$ & $\begin{array}{l}\text { Specific } \\
\text { gravity } \\
\left(20^{\circ} \mathrm{C}\right)\end{array}$ \\
\hline Aluminum & $\mathrm{Al}$ & 13 & 26.98 & 660.4 & 2467 & 2.70 \\
Beryli1um & $\mathrm{Be}$ & 4 & 9.01 & 1278.0 & 2970 & 1.85 \\
Boron & $\mathrm{B}$ & 5 & 10.81 & 2300.0 & 2550 & 2.34 \\
Carbon & $\mathrm{C}$ & 6 & 12.01 & 3550.0 & 4827 & 2.26 \\
Iron & $\mathrm{Fe}$ & 26 & 55.85 & 1535.0 & 2750 & 7.87 \\
Lithium & $\mathrm{Li}$ & 3 & 6.94 & 180.5 & 1342 & 0.53 \\
Magnesium & $\mathrm{Mg}$ & 12 & 24.31 & 648.8 & 1090 & 1.74 \\
\hline
\end{tabular}


TABLE II. - METALLIZEO PROPELLANT PEAK THEORETICAL VACUUM SPECIFIC IMPULSE [Idea] expansion; $P_{C}=6.895 \mathrm{MN} / \mathrm{m}^{2}(1000 \mathrm{psia}) ; \varepsilon=60: 1$. ]

\begin{tabular}{|c|c|c|c|}
\hline $\begin{array}{l}\text { Propel lant } \\
\text { combination }\end{array}$ & $\begin{array}{c}\text { Oxidizer to } \\
\text { total fuel } \\
\text { ratio, } \\
0 / F\end{array}$ & $\begin{array}{l}\text { Metal in } \\
\text { fuel, } \\
\text { wt } \%\end{array}$ & $\begin{array}{c}\text { Vacuum specific } \\
\text { impuise, } \\
\text { sec }\end{array}$ \\
\hline $\mathrm{H}_{2} / \mathrm{O}_{2}$ & 5.0 & 0 & 462.0 \\
\hline $\mathrm{Be} / \mathrm{H}_{2} / \mathrm{O}_{2}$ & 0.9 & 50 & 548.0 \\
\hline $\mathrm{A} 1 / \mathrm{H}_{2} / \mathrm{O}_{2}$ & 0.7 & 65 & 469.5 \\
\hline $\mathrm{LI} / \mathrm{H}_{2} / \mathrm{O}_{2}$ & 0.7 & 55 & 490.2 \\
\hline $\mathrm{Fe} / \mathrm{H}_{2} / \mathrm{O}_{2}$ & 5.0 & 0 & 462.0 \\
\hline $\mathrm{H}_{2} / \mathrm{F}_{2}$ & 12.0 & 0 & 486.4 \\
\hline $\mathrm{Li} / \mathrm{H}_{2} / \mathrm{F}_{2}$ & 1.1 & 40 & 528.0 \\
\hline $\mathrm{N}_{2} \mathrm{H}_{4} / \mathrm{N}_{2} \mathrm{O}_{4}$ & 1.4 & 0 & 349.2 \\
\hline $\mathrm{Be} / \mathrm{N}_{2} \mathrm{H}_{4} / \mathrm{N}_{2} \mathrm{O}_{4}$ & 0.7 & 25 & 399.6 \\
\hline $\mathrm{AT} / \mathrm{N}_{2} \mathrm{H}_{4} / \mathrm{N}_{2} \mathrm{O}_{4}$ & 0.5 & 35 & 367.7 \\
\hline $\mathrm{Li} / \mathrm{N}_{2} \mathrm{H}_{4} / \mathrm{N}_{2} \mathrm{O}_{4}$ & 0.4 & 25 & 358.1 \\
\hline $\mathrm{Fe} / \mathrm{N}_{2} \mathrm{H}_{4} / \mathrm{N}_{2} \mathrm{O}_{4}$ & 1.4 & 0 & 349.2 \\
\hline $\mathrm{RP}-1 / 0_{2}$ & 2.8 & 0 & 365.8 \\
\hline $\mathrm{Be} / \mathrm{RP}-1 / \mathrm{O}_{2}$ & 1.4 & 35 & 389.0 \\
\hline Al $/ R P-1 / 0_{2}$ & 2.5 & 10 & 365.9 \\
\hline$L I / R P-1 / 0_{2}$ & 2.8 & 0 & 365.8 \\
\hline $\mathrm{Fe} / \mathrm{RP}-1 / \mathrm{O}_{2}$ & 2.8 & 0 & 365.8 \\
\hline
\end{tabular}


table III. - PEAK VEHICle PERformance of METALLIZEd PROPELLANT SYSTEMS

\begin{tabular}{|c|c|c|c|c|c|c|c|c|}
\hline \multirow[t]{2}{*}{$\begin{array}{l}\text { Propellant } \\
\text { combination }\end{array}$} & \multirow{2}{*}{$\begin{array}{l}\text { Oxidizer to } \\
\text { total fue } 1 \\
\text { ratio, } \\
0 / F\end{array}$} & \multirow{2}{*}{$\begin{array}{l}\text { Vacuum specific } \\
\text { impulse, } \\
\text { sec }\end{array}$} & \multirow{2}{*}{$\begin{array}{l}\text { Metal in } \\
\text { fuel, } \\
\text { wt } \%\end{array}$} & \multicolumn{2}{|c|}{$\begin{array}{l}\text { Bulk propellant } \\
\text { density, } \rho_{p}\end{array}$} & \multicolumn{3}{|c|}{$\begin{array}{l}\text { Peak delivered } \\
\text { payload mass, Mpl }\end{array}$} \\
\hline & & & & $\mathrm{kg} / \mathrm{m}^{3}$ & $1 \mathrm{~b} / \mathrm{ft}^{3}$ & & $\mathrm{~kg}$ & ib \\
\hline $\mathrm{H}_{2} / \mathrm{O}_{2}$ & 8.5 & 433,8 & 0 & 441.31 & 27.55 & & 751.7 & 25908.0 \\
\hline $\mathrm{Be} / \mathrm{H}_{2} / \mathrm{O}_{2}$ & 5.5 & 394.9 & 60 & 603.42 & 37.67 & & 279.5 & 31480.9 \\
\hline A $1 / \mathrm{H}_{2} / 0_{2}$ & 1.4 & 273.0 & 100 & 1504.45 & 93.92 & & 998.5 & 41884.6 \\
\hline $\mathrm{L} / / \mathrm{H}_{2} / \mathrm{O}_{2}$ & 2.5 & 391.1 & 80 & 538.22 & 33.60 & & 202.0 & 26900.0 \\
\hline & 1.5 & 334.8 & 85 & 707.38 & 44.16 & & 292.4 & 27100.1 \\
\hline $\mathrm{H}_{2} / \mathrm{F}_{2}$ & 19.0 & 481.4 & 0 & 749.82 & 46.81 & & 180.6 & 57718.4 \\
\hline $\mathrm{L}+/ \mathrm{H}_{2} / \mathrm{F}_{2}$ & 11.0 & 477.3 & 50 & 786.03 & 49.07 & & 185.7 & 59934.3 \\
\hline $\mathrm{N}_{2} \mathrm{H}_{4} / \mathrm{N}_{2} \mathrm{O}_{4}$ & 1.4 & 349.2 & 0 & 1215.32 & 75.87 & 25 & 067.8 & 55265.0 \\
\hline $\mathrm{Be} / \mathrm{N}_{2} \mathrm{H}_{4} / \mathrm{N}_{2} \mathrm{O}_{4}$ & 0.8 & 396.6 & 30 & 1268.66 & 79.20 & & 282.7 & $73 \quad 375.9$ \\
\hline $\mathrm{Al} / \mathrm{N}_{2} \mathrm{H}_{4} / \mathrm{N}_{2} \mathrm{O}_{4}$ & 0.7 & 359.0 & 50 & 1449.83 & 90.51 & & 063.8 & 70688.6 \\
\hline $\mathrm{Li} / \mathrm{N}_{2} \mathrm{H}_{4} / \mathrm{N}_{2} \mathrm{O}_{4}$ & 1.4 & 349.2 & 0 & 1215.32 & 75.87 & & 067.8 & 55265.0 \\
\hline $\mathrm{Fe} / \mathrm{N}_{2} \mathrm{H}_{4} / \mathrm{N}_{2} \mathrm{O}_{4}$ & 1.3 & 337.1 & 15 & 1296.05 & 80.91 & & 127.2 & 55396.0 \\
\hline $\mathrm{RP}-1 / 0_{2}$ & 2.9 & 365.6 & 0 & 1017.97 & 63.55 & & 478.5 & 49556.7 \\
\hline$B e / R P-1 / 0_{2}$ & 1.4 & 385.9 & 40 & 1082.37 & 67.57 & 26 & 632.1 & 58713.8 \\
\hline A $1 / R P-1 / 0_{2}$ & 1.0 & 348.6 & 65 & 1275.07 & 79.60 & 26 & 348.4 & 58088.2 \\
\hline $\mathrm{L} 1 / \mathrm{RP}-1 / 0_{2}$ & 2.9 & 365.6 & 0 & 1017.97 & 63.55 & & 478.5 & 49556.7 \\
\hline $\mathrm{Fe} / \mathrm{RP}-1 / 0_{2}$ & 2.9 & 365.6 & 0 & 1017.97 & 63.55 & & 478.5 & $49 \quad 556.7$ \\
\hline
\end{tabular}

TABLE IV. - EFFECT OF METAL LOAding ON VEHICLE PERFORMANCE FOR Be/H $/ \mathrm{H}_{2} / \mathrm{O}_{2}$

$\left[\Delta V=4267.2 \mathrm{~m} / \mathrm{sec}(14000 \mathrm{ft} / \mathrm{sec}) ; M_{d r y}=2761.6 \mathrm{~kg}(6000 \mathrm{lb})\right.$;

$\left.v_{p}=56.63 \mathrm{~m}^{3}\left(2000 \mathrm{ft}^{3}\right) \cdot\right]$

\begin{tabular}{|c|c|c|c|c|c|c|c|}
\hline \multirow{2}{*}{$\begin{array}{l}\text { Beryllium } \\
\text { in fuel. } \\
\text { wt } x\end{array}$} & \multirow{2}{*}{$\begin{array}{c}\text { Ratio of } \\
\text { oxidizer } \\
\text { to total } \\
\text { fuel, } \\
\text { o/f }\end{array}$} & \multirow{2}{*}{$\begin{array}{l}\text { Vacuum } \\
\text { specific } \\
\text { impuise, } \\
\text { sec }\end{array}$} & \multicolumn{2}{|c|}{$\begin{array}{l}\text { Bulk propellant } \\
\text { density, } \rho_{p}\end{array}$} & \multirow{2}{*}{$\begin{array}{c}\rho_{p} I_{s p}^{2} \\
\mathrm{~kg} \cdot \mathrm{s}^{2} / \mathrm{m}^{3}\end{array}$} & \multicolumn{2}{|c|}{$\begin{array}{l}\text { Maximum payload } \\
\text { mass, Mpl }\end{array}$} \\
\hline & & & $\mathrm{kg} / \mathrm{m}^{3}$ & $1 b / f t^{3}$ & & $\mathrm{~kg}$ & $1 \mathrm{~b}$ \\
\hline $\begin{array}{r}0 \\
5 \\
10 \\
15 \\
20 \\
25 \\
30 \\
35 \\
40 \\
45 \\
50 \\
55 \\
60\end{array}$ & $\begin{array}{l}8.5 \\
8.5 \\
8.0 \\
8.0 \\
7.5 \\
7.5 \\
7.0 \\
7.0 \\
6.5 \\
6.5 \\
6.0 \\
5.5 \\
5.5\end{array}$ & $\begin{array}{l}433.8 \\
427.4 \\
429.8 \\
423.3 \\
425.5 \\
418.7 \\
420.5 \\
413.0 \\
414.1 \\
405.7 \\
405.8 \\
405.3 \\
394.9\end{array}$ & $\begin{array}{l}441.31 \\
455.56 \\
456.04 \\
472.22 \\
473.67 \\
492.25 \\
495.29 \\
517.08 \\
522.36 \\
548.15 \\
557.12 \\
567.69 \\
603.42\end{array}$ & $\begin{array}{l}27.55 \\
28.44 \\
28.47 \\
29.48 \\
29.57 \\
30.73 \\
30.92 \\
32.28 \\
32.67 \\
34.22 \\
34.78 \\
35.44 \\
37.67\end{array}$ & $\begin{array}{l}83.046 \times 10^{6} \\
83.218 \\
84.244 \\
84.614 \\
85.757 \\
86.296 \\
87.578 \\
88.197 \\
89.574 \\
90.222 \\
91.743 \\
93.254 \\
94.100\end{array}$ & $\begin{array}{ll}11 & 757.7 \\
11 & 873.2 \\
12 & 017.0 \\
12 & 174.4 \\
12 & 345.5 \\
12 & 537.5 \\
12 & 737.7 \\
12 & 953.5 \\
13 & 183.2 \\
13 & 424.8 \\
13 & 692.2 \\
13 & 970.4 \\
14 & 279.5\end{array}$ & $\begin{array}{ll}25 & 908.0 \\
26 & 175.9 \\
26 & 493.0 \\
26 & 840.0 \\
27 & 217.1 \\
27 & 640.8 \\
28 & 087.9 \\
28 & 557.5 \\
29 & 064.0 \\
29 & 596.7 \\
30 & 186.2 \\
30 & 799.4 \\
31 & 480.9\end{array}$ \\
\hline
\end{tabular}


TABLE V. - EFFECT OF METAL LOADING ON VEHICLE PERFORMANCE FOR Be/ $/ \mathrm{N}_{2} \mathrm{H}_{4} / \mathrm{N}_{2} \mathrm{O}_{4}$ $\left[\Delta V=4267.2 \mathrm{~m} / \mathrm{sec}(14000 \mathrm{ft} / \mathrm{sec}) ; M_{d r y}=2761.6 \mathrm{~kg}(6000 \mathrm{lb})\right.$; $\left.v_{p}=56.63 \mathrm{~m}^{3}\left(2000 \mathrm{ft}^{3}\right).\right]$

\begin{tabular}{|c|c|c|c|c|c|c|c|}
\hline \multirow{2}{*}{$\begin{array}{l}\text { Beryllium } \\
\text { in fuel, } \\
\text { wt } x\end{array}$} & \multirow{2}{*}{$\begin{array}{l}\text { Ratio of } \\
\text { oxidizer } \\
\text { to total } \\
\text { fuel, } \\
0 / F \\
\end{array}$} & \multirow{2}{*}{$\begin{array}{c}\text { Vacuum } \\
\text { specific } \\
\text { impulse, } \\
\text { sec }\end{array}$} & \multicolumn{2}{|c|}{$\begin{array}{l}\text { Bulk propellant } \\
\text { density, } \rho_{p}\end{array}$} & \multirow{2}{*}{$\begin{array}{c}\rho_{p} I_{s p}^{2} \\
\mathrm{~kg} \cdot \mathrm{s}^{2} / \mathrm{m}^{3}\end{array}$} & \multicolumn{2}{|c|}{$\begin{array}{l}\text { Maximum payload } \\
\text { mass, } M_{p l} l\end{array}$} \\
\hline & & & $\mathrm{kg} / \mathrm{m}^{3}$ & $\mathrm{lb} / \mathrm{ft}^{3}$ & & $\mathrm{~kg}$ & $1 b$ \\
\hline $\begin{array}{r}0 \\
5 \\
10 \\
15 \\
20 \\
25 \\
30 \\
35 \\
40 \\
45 \\
50\end{array}$ & $\begin{array}{l}1.4 \\
1.4 \\
1.4 \\
1.1 \\
0.6 \\
0.7 \\
0.8 \\
0.9 \\
1.0 \\
1.1 \\
1.2\end{array}$ & $\begin{array}{l}349.2 \\
360.0 \\
368.1 \\
378.8 \\
396.4 \\
399.6 \\
396.6 \\
390.0 \\
382.1 \\
374.7 \\
368.1\end{array}$ & $\begin{array}{l}1215.32 \\
1229.42 \\
1243.99 \\
1237.59 \\
1207.95 \\
1239.35 \\
1268.66 \\
1296.21 \\
1322.00 \\
1346.19 \\
1368.94\end{array}$ & $\begin{array}{l}75.87 \\
76.75 \\
77.66 \\
77.26 \\
75.41 \\
77.37 \\
79.20 \\
80.92 \\
82.53 \\
84.04 \\
85.46\end{array}$ & $\begin{array}{l}148.197 \times 10^{6} \\
159.332 \\
168.558 \\
177.581 \\
189.809 \\
197.899 \\
199.550 \\
197.154 \\
193.013 \\
189.005 \\
185.438\end{array}$ & $\begin{array}{ll}25 & 067.8 \\
26 & 919.0 \\
28 & 435.1 \\
29 & 816.3 \\
31 & 529.2 \\
32 & 888.3 \\
33 & 282.7 \\
33 & 055.6 \\
32 & 542.5 \\
32 & 025.4 \\
31 & 563.3\end{array}$ & $\begin{array}{ll}55 & 265.0 \\
59 & 346.2 \\
62 & 688.7 \\
65 & 733.6 \\
69 & 510.1 \\
72 & 506.4 \\
73 & 375.9 \\
72 & 875.2 \\
71 & 743.9 \\
70 & 604.0 \\
69 & 585.2\end{array}$ \\
\hline
\end{tabular}

TABLE VI. - EFFECT OF METAL LOADING ON VEHICLE PERFORMANCE FOR Be/RP- $1 / 0_{2}$ $\left[\Delta V=4267.2 \mathrm{~m} / \mathrm{sec}(14000 \mathrm{ft} / \mathrm{sec}) ; M_{d r y}=2761.6 \mathrm{~kg}(6000 \mathrm{lb}) ;\right.$

$\left.V_{p}=56.63 \mathrm{~m}^{3}\left(2000 \mathrm{ft}^{3}\right).\right]$

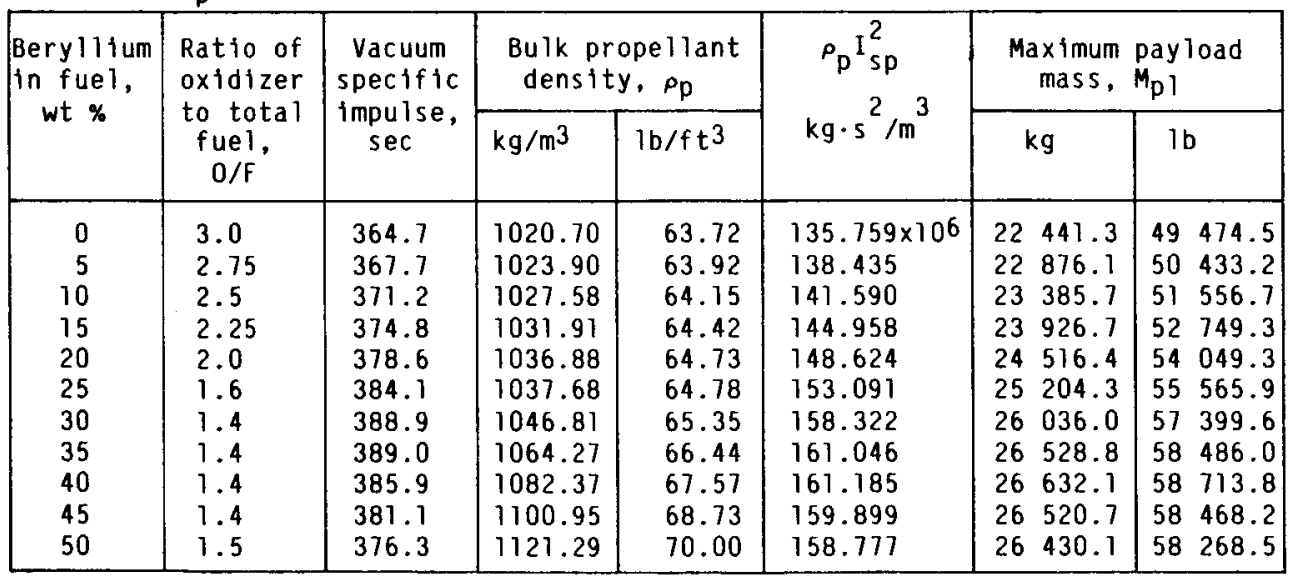


TABLE VII. - EFFECT OF METAL LOADING ON VEHICLE PERFORMANCE FOR Li/H $/ \mathrm{H}_{2} / \mathrm{O}_{2}$

$\left[\Delta V=4267.2 \mathrm{~m} / \mathrm{sec}(14000 \mathrm{ft} / \mathrm{sec}) ; M_{d r y}=2761.6 \mathrm{~kg}(6000 \mathrm{lb})\right.$;

$\left.v_{p}=56.63 \mathrm{~m}^{3}\left(2000 \mathrm{ft}^{3}\right).\right]$

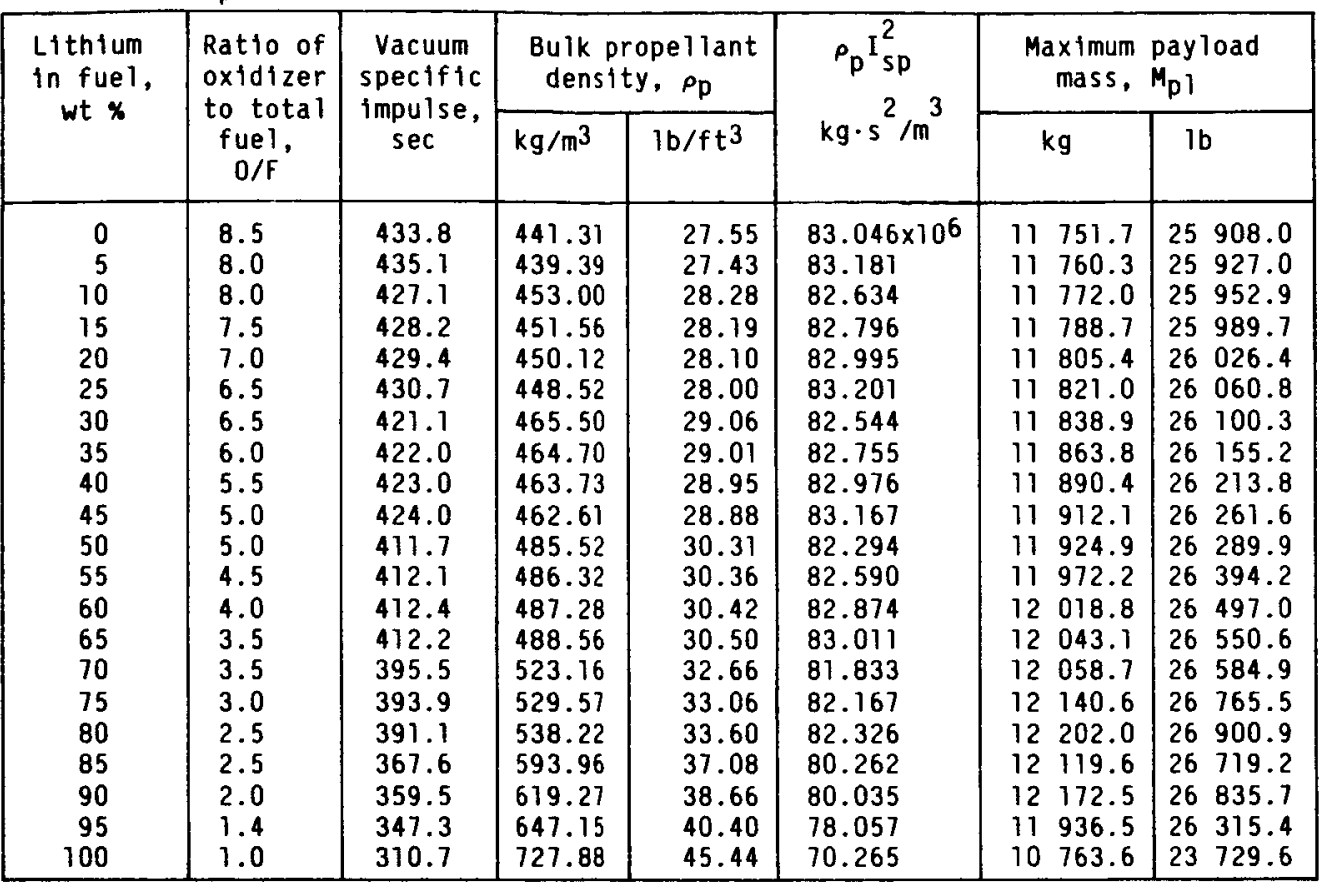

TABLE VIII. - EFFECT OF METAL LOADING ON VEHICLE PERFORMANCE FOR Li/N $\mathrm{N}_{2} \mathrm{H}_{4} / \mathrm{N}_{2} \mathrm{O}_{4}$

$\left[\Delta V=4267.2 \mathrm{~m} / \mathrm{sec}(14000 \mathrm{ft} / \mathrm{sec}) ; M_{d r y}=2761.6 \mathrm{~kg}(6000 \mathrm{lb}) ;\right.$

$\left.v_{p}=56.63 \mathrm{~m}^{3}\left(2000 \mathrm{ft}^{3}\right).\right]$

\begin{tabular}{|c|c|c|c|c|c|c|c|}
\hline \multirow{2}{*}{$\begin{array}{l}\text { Lithium } \\
\text { in fuel, } \\
\text { wt } x\end{array}$} & \multirow{2}{*}{$\begin{array}{l}\text { Ratio of } \\
\text { oxidizer } \\
\text { to total } \\
\text { fuel, } \\
0 / F\end{array}$} & \multirow{2}{*}{$\begin{array}{l}\text { Vacuum } \\
\text { speciftic } \\
\text { impulse, } \\
\text { sec }\end{array}$} & \multicolumn{2}{|c|}{$\begin{array}{l}\text { Bulk propellant } \\
\text { density, } \rho_{p}\end{array}$} & \multirow{2}{*}{$\begin{array}{c}e_{p} I_{s p}^{2} \\
\mathrm{~kg} \cdot \mathrm{s}^{2} / \mathrm{m}^{3}\end{array}$} & \multicolumn{2}{|c|}{$\begin{array}{c}\text { Maximum payload } \\
\text { mass, Mpl }\end{array}$} \\
\hline & & & $\mathrm{kg} / \mathrm{m}^{3}$ & $1 \mathrm{~b} / \mathrm{ft}^{3}$ & & $\mathrm{~kg}$ & $1 b$ \\
\hline $\begin{array}{r}0 \\
5 \\
10 \\
15 \\
20 \\
25 \\
30 \\
35 \\
40 \\
45 \\
50 \\
55 \\
60 \\
65 \\
70 \\
75 \\
80 \\
85 \\
90 \\
95 \\
100\end{array}$ & $\begin{array}{l}1.4 \\
1.4 \\
1.4 \\
1.4 \\
1.4 \\
1.5 \\
1.5 \\
1.5 \\
1.5 \\
1.5 \\
1.5 \\
1.5 \\
1.5 \\
1.5 \\
1.5 \\
1.5 \\
1.5 \\
1.5 \\
1.6 \\
1.7 \\
2.0\end{array}$ & $\begin{array}{l}349.2 \\
349.3 \\
348.6 \\
347.6 \\
346.4 \\
343.6 \\
342.4 \\
341.2 \\
339.8 \\
338.3 \\
337.0 \\
335.4 \\
333.4 \\
330.9 \\
328.0 \\
324.6 \\
320.9 \\
316.8 \\
309.9 \\
303.0 \\
292.7\end{array}$ & $\begin{array}{r}1215.32 \\
1188.89 \\
1163.74 \\
1139.39 \\
1116.33 \\
1104.31 \\
1083.49 \\
1063.30 \\
1043.76 \\
1025.02 \\
1006.92 \\
989.46 \\
972.64 \\
956.30 \\
940.60 \\
925.39 \\
910.65 \\
896.23 \\
895.59 \\
894.95 \\
977.38\end{array}$ & $\begin{array}{l}75.87 \\
74.22 \\
72.65 \\
71.13 \\
69.69 \\
68.94 \\
67.64 \\
66.38 \\
65.16 \\
63.99 \\
62.86 \\
61.77 \\
60.72 \\
59.70 \\
58.72 \\
57.77 \\
56.85 \\
55.95 \\
55.91 \\
55.87 \\
57.27\end{array}$ & $\begin{array}{l}148.197 \times 106 \\
145.057 \\
141.420 \\
137.668 \\
133.951 \\
130.376 \\
127.026 \\
123.787 \\
120.517 \\
117.310 \\
114.355 \\
111.308 \\
108.114 \\
104.710 \\
101.194 \\
97.504 \\
93.776 \\
89.948 \\
86.011 \\
82.165 \\
78.595\end{array}$ & $\begin{array}{ll}25 & 067.8 \\
24 & 478.4 \\
23 & 807.5 \\
23 & 125.4 \\
22 & 445.7 \\
21 & 824.6 \\
21 & 210.5 \\
20 & 619.3 \\
20 & 026.2 \\
19 & 442.9 \\
18 & 903.2 \\
18 & 348.8 \\
17 & 769.4 \\
17 & 155.9 \\
16 & 520.7 \\
15 & 854.9 \\
15 & 180.8 \\
14 & 489.2 \\
13 & 790.1 \\
13 & 097.7 \\
12 & 460.5\end{array}$ & $\begin{array}{ll}55 & 265.0 \\
53 & 965.7 \\
52 & 486.5 \\
50 & 982.8 \\
49 & 484.2 \\
48 & 115.0 \\
46 & 761.1 \\
45 & 457.8 \\
44 & 150.2 \\
42 & 864.2 \\
41 & 674.5 \\
40 & 452.2 \\
39 & 174.9 \\
37 & 822.2 \\
36 & 421.9 \\
34 & 954.1 \\
33 & 468.0 \\
31 & 943.3 \\
30 & 402.0 \\
28 & 875.4 \\
27 & 470.8\end{array}$ \\
\hline
\end{tabular}


TABLE IX. - EFFECT OF METAL LOADING ON VEHICLE PERFORMANCE FOR Li/RP $-1 / 0_{2}$ $\left[\Delta V=4267.2 \mathrm{~m} / \mathrm{sec}(14000 \mathrm{ft} / \mathrm{sec}) ; M_{d r y}=2761.6 \mathrm{~kg}(6000 \mathrm{lb}) ;\right.$

$\left.v_{p}=56.63 \mathrm{~m}^{3}\left(2000 \mathrm{ft}^{3}\right).\right]$

\begin{tabular}{|c|c|c|c|c|c|c|c|c|c|}
\hline \multirow{2}{*}{$\begin{array}{c}\text { Lithium } \\
\text { in fuel, } \\
\text { wt } \%\end{array}$} & \multirow{2}{*}{$\begin{array}{l}\text { Ratio of } \\
\text { oxidizer } \\
\text { to total } \\
\text { fuel, } \\
0 / f\end{array}$} & \multirow{2}{*}{$\begin{array}{c}\text { Vacuum } \\
\text { specif ic } \\
\text { impulse, } \\
\text { sec }\end{array}$} & \multicolumn{2}{|c|}{$\begin{array}{l}\text { Bulk propellant } \\
\text { density, } \rho_{p}\end{array}$} & \multirow{2}{*}{$\begin{array}{l}\rho_{p} I_{s p}^{2} \\
\mathrm{~kg} \cdot \mathrm{s}^{2} / \mathrm{m}^{3}\end{array}$} & \multicolumn{4}{|c|}{$\begin{array}{c}\text { Maximum payload } \\
\text { mass, } M_{p l}\end{array}$} \\
\hline & & & $\mathrm{kg} / \mathrm{m}^{3}$ & $\mathrm{lb} / \mathrm{ft} \mathrm{t}^{3}$ & & & $\mathrm{~kg}$ & 1 & \\
\hline 0 & 2.9 & 365.6 & 1017.97 & 63.55 & $136.066 \times 10^{6}$ & & 478.5 & & 556.7 \\
\hline 5 & 2.8 & 364.6 & 1007.24 & 62.88 & 133.896 & 22 & 096.9 & 48 & 715.4 \\
\hline 10 & 2.8 & 363.1 & 999.55 & 62.40 & 131.783 & 21 & 734.6 & 47 & 916.7 \\
\hline 15 & 2.7 & 362.1 & 988.50 & 61.71 & 129.608 & 21 & 349.3 & 47 & 067.2 \\
\hline 20 & 2.6 & 361.0 & 977.13 & 61.00 & 127.340 & 20 & 946.9 & 46 & 180.0 \\
\hline 25 & 2.6 & 359.0 & 969.44 & 60.52 & 124.942 & 20 & 538.7 & 45 & 280.1 \\
\hline 30 & 2.5 & 357.8 & 957.58 & 59.78 & 122.591 & 20 & 122.5 & 44 & 362.5 \\
\hline 35 & 2.4 & 356.5 & 945.41 & 59.02 & 120.154 & 19 & 689.6 & 43 & 408.2 \\
\hline 40 & 2.3 & 355.0 & 932.76 & 58.23 & 117.550 & 19 & 229.6 & 42 & 394.0 \\
\hline 45 & 2.3 & 351.9 & 925.23 & 57.76 & 114.574 & 18 & 722.0 & 41 & 274.9 \\
\hline 50 & 2.2 & 349.7 & 912.25 & 56.95 & 111.559 & 18 & 189.1 & 40 & 100.2 \\
\hline 55 & 2.1 & 347.0 & 898.64 & 56.10 & 108.204 & 17 & 601.9 & 38 & 805.5 \\
\hline 60 & 1.9 & 345.8 & 877.81 & 54.80 & 104.967 & 17 & 070.9 & 37 & 502.6 \\
\hline 65 & 1.8 & 343.1 & 862.91 & 53.87 & 101.580 & 16 & 408.4 & 36 & 174.3 \\
\hline 70 & 1.7 & 340.1 & 847.38 & 52.90 & 99.751 & 15 & 774.7 & 34 & 777.2 \\
\hline 75 & 1.6 & 336.4 & 831.20 & 51.89 & 94.062 & 15 & 073.8 & 33 & 232.0 \\
\hline 80 & 1.5 & 332.2 & 814.54 & 50.85 & 89.890 & 14 & 328.4 & 31 & 588.8 \\
\hline 85 & 1.3 & 329.6 & 786.83 & 49.12 & 85.478 & 13 & 517.2 & 29 & 800.4 \\
\hline 90 & 1.2 & 324.2 & 768.08 & 47.95 & 80.730 & 12 & 662.1 & 27 & 915.1 \\
\hline 95 & 1.7 & 378.0 & 748.38 & 46.72 & 75.679 & 17 & 749.9 & 25 & 904.1 \\
\hline 100 & 1.0 & 310.7 & 727.88 & 45.44 & 70.265 & 10 & 763.6 & 23 & 729.6 \\
\hline
\end{tabular}

TABLE $X$. - EFFECT OF METAL LOADING ON VEHICLE PERFORMANCE FOR Li/H $/ \mathrm{F}_{2}$

$\left[\Delta V=4267.2 \mathrm{~m} / \mathrm{sec}(14000 \mathrm{ft} / \mathrm{sec}) ; M_{d r y}=2761.6 \mathrm{~kg}(6000 \mathrm{lb})\right.$;

$\left.v_{p}=56.63 \mathrm{~m}^{3}\left(2000 \mathrm{ft}^{3}\right).\right]$

\begin{tabular}{|c|c|c|c|c|c|c|c|c|}
\hline \multirow{2}{*}{$\begin{array}{l}\text { Lithium } \\
\text { in fuel, } \\
\text { wt } \%\end{array}$} & \multirow{2}{*}{$\begin{array}{l}\text { Ratio of } \\
\text { oxidizer } \\
\text { to total } \\
\text { fuel, } \\
0 / F\end{array}$} & \multirow{2}{*}{$\begin{array}{l}\text { Vacuum } \\
\text { specific } \\
\text { impulse, } \\
\text { sec }\end{array}$} & \multicolumn{2}{|c|}{$\begin{array}{l}\text { Bulk propellant } \\
\text { density, } \rho_{p}\end{array}$} & \multirow{2}{*}{$\begin{array}{c}\rho_{p} \mathrm{I}_{\mathrm{sp}}^{2} \\
\mathrm{~kg} \cdot \mathrm{s}^{2} / \mathrm{m}^{3}\end{array}$} & \multicolumn{3}{|c|}{$\begin{array}{l}\text { Maximum payload } \\
\text { mass, } M_{p l}\end{array}$} \\
\hline & & & $\mathrm{kg} / \mathrm{m}^{3}$ & $1 b / f t^{3}$ & & $\mathrm{~kg}$ & $1 \mathrm{~b}$ & \\
\hline $\begin{array}{r}0 \\
5 \\
10 \\
15 \\
20 \\
25 \\
30 \\
35 \\
40 \\
45 \\
50\end{array}$ & $\begin{array}{l}19.0 \\
19.0 \\
18.0 \\
17.0 \\
16.0 \\
15.0 \\
14.0 \\
14.0 \\
13.0 \\
12.0 \\
11.0\end{array}$ & $\begin{array}{l}481.4 \\
473.9 \\
475.4 \\
476.9 \\
478.4 \\
479.9 \\
481.1 \\
471.8 \\
473.6 \\
475.4 \\
477.3\end{array}$ & $\begin{array}{l}749.82 \\
767.28 \\
766.48 \\
765.36 \\
764.24 \\
762.96 \\
761.52 \\
785.86 \\
785.86 \\
786.03 \\
786.03\end{array}$ & $\begin{array}{l}46.81 \\
47.90 \\
47.85 \\
47.78 \\
47.71 \\
47.63 \\
47.54 \\
49.06 \\
49.06 \\
49.07 \\
49.07\end{array}$ & $\begin{array}{l}173.769 \times 10^{6} \\
172.318 \\
173.229 \\
174.069 \\
174.909 \\
175.713 \\
176.259 \\
174.930 \\
176.267 \\
177.646 \\
179.069\end{array}$ & $\begin{array}{ll}26 & 180.6 \\
26 & 158.8 \\
26 & 263.5 \\
26 & 364.0 \\
26 & 459.8 \\
26 & 549.9 \\
26 & 605.4 \\
26 & 656.4 \\
26 & 829.4 \\
27 & 002.6 \\
27 & 185.7\end{array}$ & $\begin{array}{l}57 \\
57 \\
57 \\
58 \\
58 \\
58 \\
58 \\
58 \\
59 \\
59 \\
59\end{array}$ & $\begin{array}{l}718.4 \\
670.4 \\
901.1 \\
122.8 \\
334.0 \\
532.6 \\
654.9 \\
767.3 \\
148.6 \\
530.5 \\
934.3\end{array}$ \\
\hline
\end{tabular}


TABLE XI. - EFFECT OF METAL LOADING ON VEHICLE PERFORMANCE FOR AI/ $\mathrm{H}_{2} / \mathrm{O}_{2}$

$\left[\Delta V=4267.2 \mathrm{~m} / \mathrm{sec}(14000 \mathrm{ft} / \mathrm{sec}) ; M_{d r y}=2761.6 \mathrm{~kg}(6000 \mathrm{lb})\right.$;

$\left.V_{p}=56.63 \mathrm{~m}^{3}\left(2000 \mathrm{ft}^{3}\right).\right]$

\begin{tabular}{|c|c|c|c|c|c|c|c|}
\hline \multirow{2}{*}{$\begin{array}{l}\text { Aluminum } \\
\text { in fuel, } \\
\text { wt } x\end{array}$} & \multirow{2}{*}{$\begin{array}{c}\text { Ratio of } \\
\text { oxidizer } \\
\text { to total } \\
\text { fuel, } \\
\text { O/F }\end{array}$} & \multirow{2}{*}{$\begin{array}{c}\text { Vacuum } \\
\text { specific } \\
\text { Impulse, } \\
\text { sec }\end{array}$} & \multicolumn{2}{|c|}{$\begin{array}{l}\text { Bulk propellant } \\
\text { density, op }\end{array}$} & \multirow{2}{*}{$\begin{array}{c}\rho_{p} I_{s p}^{2} \\
\mathrm{~kg} \cdot \mathrm{s}^{2} / \mathrm{m}^{3}\end{array}$} & \multicolumn{2}{|c|}{$\begin{array}{l}\text { Maximum payload } \\
\text { mass, Mpl }\end{array}$} \\
\hline & & & $\mathrm{kg} / \mathrm{m}^{3}$ & $\mathrm{lb} / \mathrm{ft}^{3}$ & & $\mathrm{~kg}$ & ib \\
\hline $\begin{array}{r}0 \\
5 \\
10 \\
15 \\
20 \\
25 \\
30 \\
35 \\
40 \\
45 \\
50 \\
55 \\
60 \\
65 \\
70 \\
75 \\
80 \\
85 \\
90 \\
95 \\
100\end{array}$ & $\begin{array}{l}8.5 \\
8.5 \\
8.0 \\
7.5 \\
7.0 \\
7.0 \\
6.5 \\
6.0 \\
6.0 \\
5.5 \\
5.0 \\
4.5 \\
4.0 \\
3.5 \\
3.5 \\
3.0 \\
2.5 \\
1.5 \\
1.1 \\
1.0 \\
1.4\end{array}$ & $\begin{array}{l}433.8 \\
426.4 \\
427.6 \\
428.9 \\
430.2 \\
421.5 \\
422.3 \\
423.2 \\
413.0 \\
413.1 \\
413.0 \\
412.5 \\
411.7 \\
410.4 \\
394.2 \\
390.0 \\
383.8 \\
391.0 \\
371.4 \\
327.8 \\
273.0\end{array}$ & $\begin{array}{r}441.31 \\
455.72 \\
456.37 \\
457.17 \\
457.81 \\
476.55 \\
478.79 \\
481.52 \\
505.38 \\
510.67 \\
516.92 \\
524.76 \\
534.22 \\
546.39 \\
596.05 \\
622.48 \\
660.12 \\
668.29 \\
776.41 \\
1035.59 \\
1504.45\end{array}$ & $\begin{array}{l}27.55 \\
28.45 \\
28.49 \\
28.54 \\
28.58 \\
29.75 \\
29.89 \\
30.06 \\
31.55 \\
31.88 \\
32.27 \\
32.76 \\
33.35 \\
34.11 \\
37.21 \\
38.86 \\
41.21 \\
41.72 \\
48.47 \\
64.65 \\
93.92\end{array}$ & $\begin{array}{l}83.046 \times 10^{6} \\
82.859 \\
83.443 \\
84.098 \\
84.727 \\
84.665 \\
85.386 \\
86.238 \\
86.203 \\
87.146 \\
88.170 \\
89.292 \\
90.548 \\
92.027 \\
92.622 \\
94.679 \\
97.237 \\
102.169 \\
107.097 \\
111.278 \\
112.126\end{array}$ & $\begin{array}{ll}11 & 751.7 \\
11 & 824.7 \\
11 & 909.7 \\
12 & 002.8 \\
12 & 099.0 \\
12 & 209.7 \\
12 & 326.3 \\
12 & 460.1 \\
12 & 598.6 \\
12 & 766.0 \\
12 & 952.6 \\
13 & 155.3 \\
13 & 394.0 \\
13 & 677.0 \\
14 & 026.2 \\
14 & 461.1 \\
15 & 019.4 \\
15 & 802.7 \\
17 & 020.4 \\
18 & 440.5 \\
18 & 998.5\end{array}$ & $\begin{array}{ll}25 & 908.0 \\
26 & 069.0 \\
26 & 256.5 \\
26 & 461.7 \\
26 & 673.7 \\
26 & 917.8 \\
27 & 174.9 \\
27 & 469.9 \\
27 & 775.2 \\
28 & 144.3 \\
28 & 555.5 \\
29 & 002.5 \\
29 & 528.7 \\
30 & 152.6 \\
30 & 922.6 \\
31 & 891.2 \\
33 & 112.1 \\
34 & 839.1 \\
37 & 523.5 \\
40 & 654.3 \\
41 & 884.6\end{array}$ \\
\hline
\end{tabular}

TABLE XII. - EFFECT OF METAL LOADING ON VEHICLE PERfORMANCE FOR AI $/ \mathrm{N}_{2} \mathrm{H}_{4} / \mathrm{N}_{2} \mathrm{O}_{4}$

$\left[\Delta V=4267.2 \mathrm{~m} / \mathrm{sec}(14000 \mathrm{ft} / \mathrm{sec}) ; M_{\mathrm{dry}}=2761.6 \mathrm{~kg}(6000 \mathrm{lb})\right.$;

$\left.v_{p}=56.63 \mathrm{~m}^{3}\left(2000 \mathrm{ft}^{3}\right).\right]$

\begin{tabular}{|c|c|c|c|c|c|c|c|}
\hline \multirow{2}{*}{$\begin{array}{c}\text { Aluminum } \\
\text { in fuel, } \\
\text { wt } x\end{array}$} & \multirow{2}{*}{$\begin{array}{l}\text { Ratio of } \\
\text { oxidizer } \\
\text { to total } \\
\text { fuel, } \\
0 / F\end{array}$} & \multirow{2}{*}{$\begin{array}{l}\text { Vacuum } \\
\text { specific } \\
\text { impulse, } \\
\text { sec }\end{array}$} & \multicolumn{2}{|c|}{$\begin{array}{l}\text { Bulk prope } 1 \text { lant } \\
\text { density, } \rho_{p}\end{array}$} & \multirow{2}{*}{$\begin{array}{c}\rho_{p} I_{s p}^{2} \\
\mathrm{~kg} \cdot \mathrm{s}^{2} / \mathrm{m}^{3}\end{array}$} & \multicolumn{2}{|c|}{$\begin{array}{l}\text { Maximum payload } \\
\text { mass, } M_{p l}\end{array}$} \\
\hline & & & $\mathrm{kg} / \mathrm{m}^{3}$ & $\mathrm{lb} / \mathrm{ft}^{3}$ & & kg & $1 b$ \\
\hline $\begin{array}{r}0 \\
5 \\
10 \\
15 \\
20 \\
25 \\
30 \\
35 \\
40 \\
45 \\
50 \\
55 \\
60 \\
65 \\
70 \\
75 \\
80 \\
85 \\
90 \\
95 \\
100\end{array}$ & $\begin{array}{l}1.4 \\
1.4 \\
1.4 \\
1.3 \\
1.3 \\
1.1 \\
0.9 \\
0.6 \\
0.6 \\
0.6 \\
0.7 \\
0.7 \\
0.8 \\
0.8 \\
0.9 \\
0.9 \\
0.9 \\
1.0 \\
1.1 \\
1.4 \\
1.4\end{array}$ & $\begin{array}{l}349.2 \\
352.7 \\
355.2 \\
357.8 \\
359.0 \\
361.7 \\
364.0 \\
367.3 \\
367.5 \\
364.7 \\
359.0 \\
353.1 \\
346.5 \\
338.2 \\
330.5 \\
321.3 \\
311.3 \\
302.5 \\
293.2 \\
287.0 \\
277.6\end{array}$ & $\begin{array}{l}1215.32 \\
1234.86 \\
1255.05 \\
1269.94 \\
1292.37 \\
1305.50 \\
1321.68 \\
1337.06 \\
1373.10 \\
1410.91 \\
1449.83 \\
1489.56 \\
1525.60 \\
1567.25 \\
1600.56 \\
1643.97 \\
1689.63 \\
1719.58 \\
1747.61 \\
1739.12 \\
1779.49\end{array}$ & $\begin{array}{r}75.87 \\
77.09 \\
78.35 \\
79.28 \\
80.68 \\
81.50 \\
82.51 \\
83.47 \\
85.72 \\
88.08 \\
90.51 \\
92.99 \\
95.24 \\
97.84 \\
99.92 \\
102.63 \\
105.48 \\
107.35 \\
109.10 \\
108.57 \\
111.09\end{array}$ & $\begin{array}{l}148.197 \times 10^{6} \\
153.614 \\
158.346 \\
162.579 \\
166.562 \\
170.795 \\
175.118 \\
180.382 \\
185.446 \\
187.659 \\
186.856 \\
185.717 \\
183.167 \\
179.260 \\
174.830 \\
169.714 \\
163.738 \\
157.352 \\
150.236 \\
143.250 \\
137.131\end{array}$ & $\begin{array}{ll}25 & 067.8 \\
26 & 011.1 \\
26 & 842.2 \\
27 & 573.6 \\
28 & 285.3 \\
29 & 006.8 \\
29 & 752.7 \\
30 & 643.2 \\
31 & 571.5 \\
32 & 060.5 \\
32 & 063.8 \\
32 & 006.6 \\
31 & 693.4 \\
31 & 149.1 \\
30 & 473.5 \\
29 & 672.4 \\
28 & 691.6 \\
27 & 577.9 \\
26 & 295.5 \\
24 & 987.5 \\
23 & 838.0\end{array}$ & $\begin{array}{ll}55 & 265.0 \\
57 & 344.7 \\
59 & 176.9 \\
60 & 789.4 \\
62 & 358.4 \\
63 & 949.0 \\
65 & 593.5 \\
67 & 556.6 \\
69 & 603.2 \\
70 & 681.4 \\
70 & 688.6 \\
70 & 562.5 \\
69 & 871.9 \\
68 & 672.0 \\
67 & 182.5 \\
65 & 416.4 \\
63 & 254.1 \\
60 & 798.9 \\
57 & 971.7 \\
55 & 088.1 \\
52 & 553.9\end{array}$ \\
\hline
\end{tabular}


TABLE XIII. - EFFECT OF METAL LOAOING ON VEHICLE PERFORMANCE FOR A1/RP-1/0 $\left[\Delta V=4267.2 \mathrm{~m} / \mathrm{sec}(14000 \mathrm{ft} / \mathrm{sec}) ; M_{\text {dry }}=2761.6 \mathrm{~kg}(6000 \mathrm{lb}) ;\right.$

$\left.v_{p}=56.63 \mathrm{~m}^{3}\left(2000 \mathrm{ft}^{3}\right).\right]$

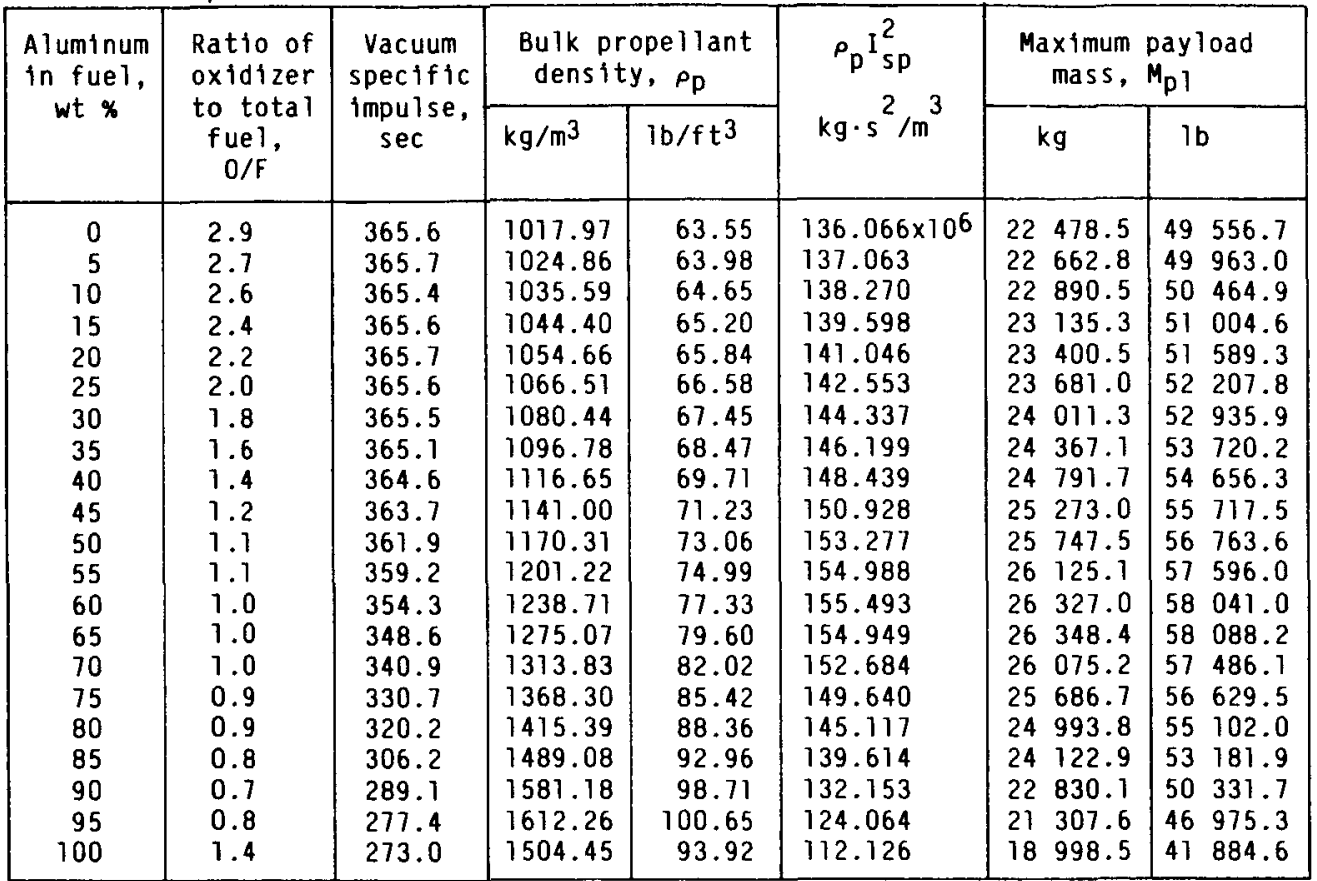

TABLE XIV. - EFFECT OF METAL LOADING ON VEHICLE PERFORMANCE FOR Fe/ $/ \mathrm{H}_{2} / \mathrm{0}_{2}$

$\left[\Delta V=4267.2 \mathrm{~m} / \mathrm{sec}(14000 \mathrm{ft} / \mathrm{sec}) ; M_{d r y}=2761.6 \mathrm{~kg}(6000 \mathrm{lb}) ;\right.$

$\left.v_{p}=56.63 \mathrm{~m}^{3}\left(2000 \mathrm{ft}^{3}\right).\right]$

\begin{tabular}{|c|c|c|c|c|c|c|c|}
\hline \multirow{2}{*}{$\begin{array}{c}\text { A Iron } \\
\text { in fuel, } \\
\text { wt } \%\end{array}$} & \multirow{2}{*}{$\begin{array}{c}\text { Ratio of } \\
\text { oxidizer } \\
\text { to total } \\
\text { fuel, } \\
0 / F\end{array}$} & \multirow{2}{*}{$\begin{array}{l}\text { Vacuum } \\
\text { specif ic } \\
\text { impulse, } \\
\text { sec }\end{array}$} & \multicolumn{2}{|c|}{$\begin{array}{l}\text { Bulk propellant } \\
\text { density, } \rho_{p}\end{array}$} & \multirow{2}{*}{$\begin{array}{c}\rho_{p} I_{s p}^{2} \\
\mathrm{~kg} \cdot \mathrm{s}^{2} / \mathrm{m}^{3}\end{array}$} & \multicolumn{2}{|c|}{$\begin{array}{l}\text { Maximum payload } \\
\text { mass, Mpl }\end{array}$} \\
\hline & & & $\mathrm{kg} / \mathrm{m}^{3}$ & $1 b / f t^{3}$ & & $\mathrm{~kg}$ & $1 b$ \\
\hline 0 & 8.5 & 433.8 & 441.31 & 27.55 & $83.046 \times 10^{6}$ & 11751.7 & 25908.0 \\
\hline 5 & 8.0 & 433.9 & 447.31 & 27.55 & 83.085 & 11758.8 & $\begin{array}{ll}25 & 923.7\end{array}$ \\
\hline 10 & 7.5 & 434.0 & 441.31 & 27.55 & 83.123 & 11766.2 & 25940.0 \\
\hline 15 & 7.5 & 424.3 & 457.97 & 28.59 & 82.448 & 780.1 & 25970.7 \\
\hline 20 & 7.0 & 424.0 & 459.09 & 28.66 & 82.533 & 11800.3 & 26015.2 \\
\hline 25 & 6.5 & 423.6 & 460.53 & 28.75 & 82.636 & 11820.0 & 26058.6 \\
\hline 30 & 6.0 & 423.0 & 461.97 & 28.84 & 82.660 & 11834.8 & $26 \quad 091.2$ \\
\hline 35 & 5.5 & 422.4 & 463.73 & 28.95 & 82.740 & 11857.0 & $26 \quad 140.3$ \\
\hline 40 & 5.5 & 409.7 & 488.08 & 30.47 & 81.927 & 11884.3 & $26 \quad 200.5$ \\
\hline 45 & 5.0 & 408.0 & 492.57 & 30.75 & 81.995 & 11918.4 & $26 \quad 275.7$ \\
\hline 50 & 4.5 & 405.9 & 497.85 & 31.08 & 82.024 & 11954.3 & 26354.8 \\
\hline 55 & 4.0 & 403.3 & 504.42 & 31.49 & 82.045 & 11993.8 & $26 \quad 441.8$ \\
\hline 60 & 3.5 & 400.1 & 512.75 & 32.01 & 82.081 & 12042.4 & $26 \quad 549.0$ \\
\hline 65 & 3.0 & 395.9 & 523.64 & 32.69 & 82.074 & 12093.6 & 26661.8 \\
\hline 70 & 3.0 & 374.0 & 576.18 & 35.97 & 80.594 & $12 \quad 105.7$ & 26688.6 \\
\hline 75 & 2.5 & 365.2 & 602.77 & 37.63 & 80.393 & 12174.3 & 26839.7 \\
\hline 80 & 2.0 & 353.0 & 642.34 & 40.10 & 80.041 & 12247.5 & 27001.1 \\
\hline 85 & 1.5 & 334.8 & 707.38 & 44.16 & 79.290 & 12292.4 & 27.100 .1 \\
\hline 90 & 1.1 & 302.0 & 844.65 & 52.73 & 77.036 & 12115.2 & 26709.5 \\
\hline 95 & 0.8 & 245.0 & 1180.08 & 73.67 & 70.834 & 10898.7 & 24027.5 \\
\hline
\end{tabular}


TABLE XV. - EFFECT OF METAL LOAOING ON VEHICLE PERFORMANCE FOR Fe/ $\mathrm{N}_{2} \mathrm{H}_{4} / \mathrm{N}_{2} \mathrm{O}_{4}$ $\left[\Delta V=4267.2 \mathrm{~m} / \mathrm{sec}(14000 \mathrm{ft} / \mathrm{sec}) ; M_{d r y}=2761.6 \mathrm{~kg}(6000 \mathrm{lb})\right.$;

$\left.v_{p}=56.63 \mathrm{~m}^{3}\left(2000 \mathrm{ft}^{3}\right).\right]$

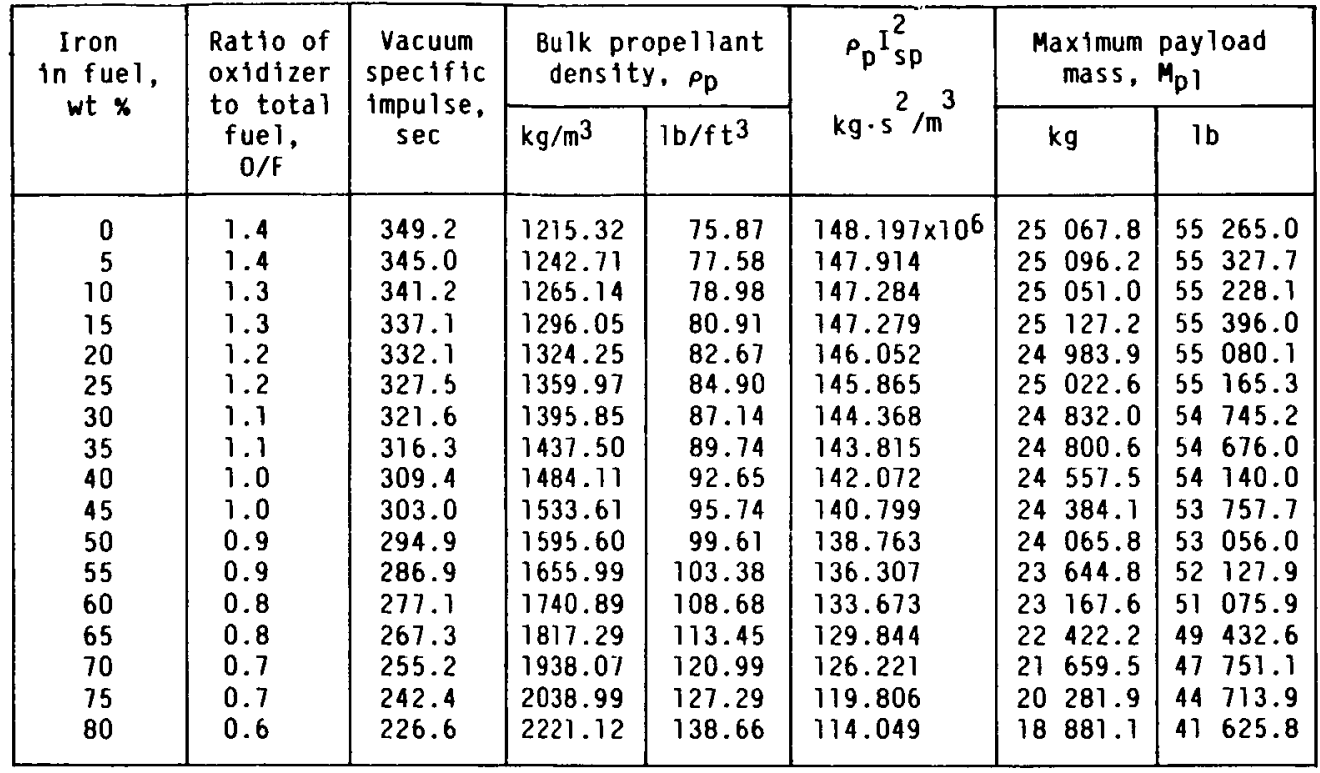

TABLE XVI. - EFFECT OF METAL LOADING ON VEHICLE PERFORMANCE FOR Fe/RP- $1 / 0_{2}$ $\left[\Delta V=4267.2 \mathrm{~m} / \mathrm{sec}(14000 \mathrm{ft} / \mathrm{sec}) ; M_{d r y}=2761.6 \mathrm{~kg}(6000 \mathrm{lb})\right.$;

$\left.V_{p}=56.63 \mathrm{~m}^{3}\left(2000 \mathrm{ft}^{3}\right).\right]$

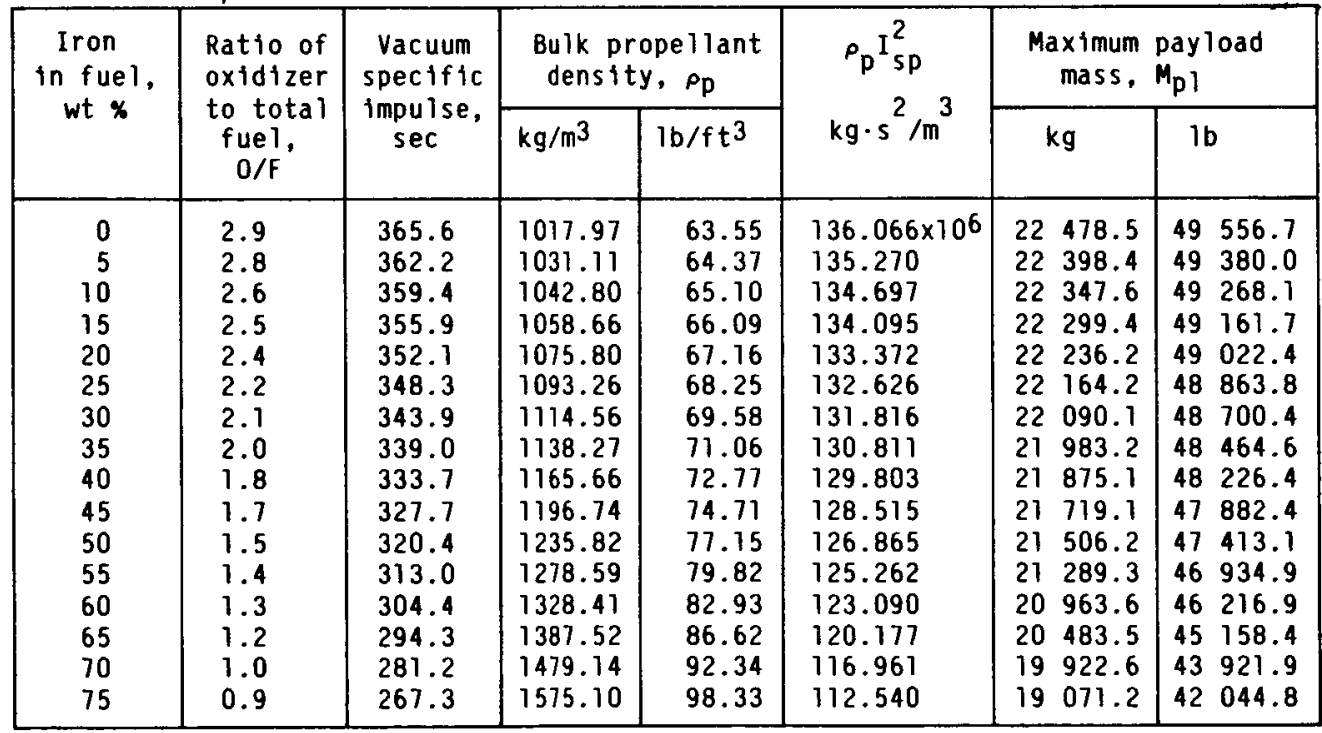




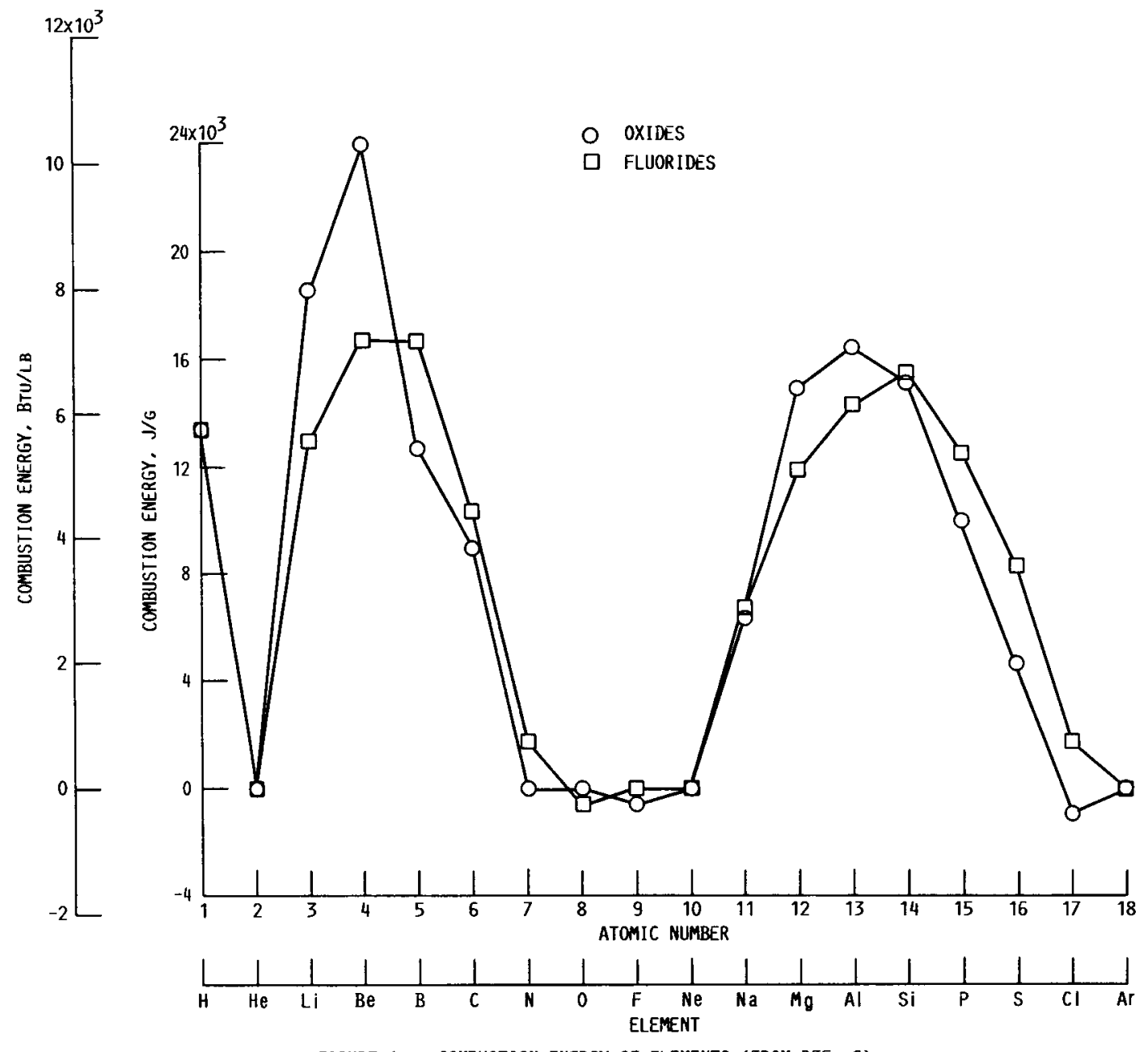

FIGURE 1. - COMBUSTION ENERGY OF ELEMENTS (FROM REF. 6).

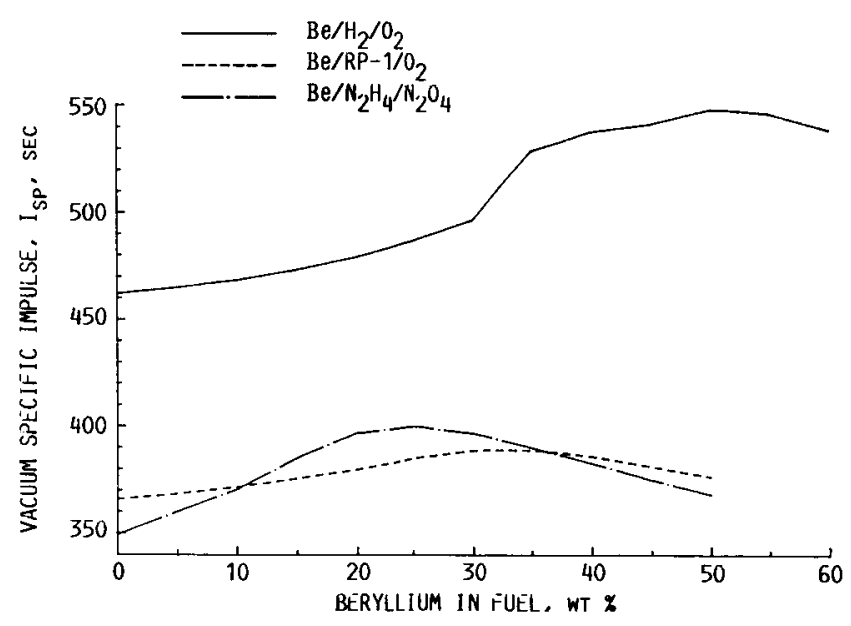

FIGURE 2. - PERFORMANCE OF BERYLLIUM AS A ROCKET PROPELLANT. $P_{c}, 6.895 \mathrm{MN} / \mathrm{M}^{2}$ ( $\left.1000 \mathrm{PSIA}\right): \varepsilon .60: 1$; IDEAL EXPANSION.

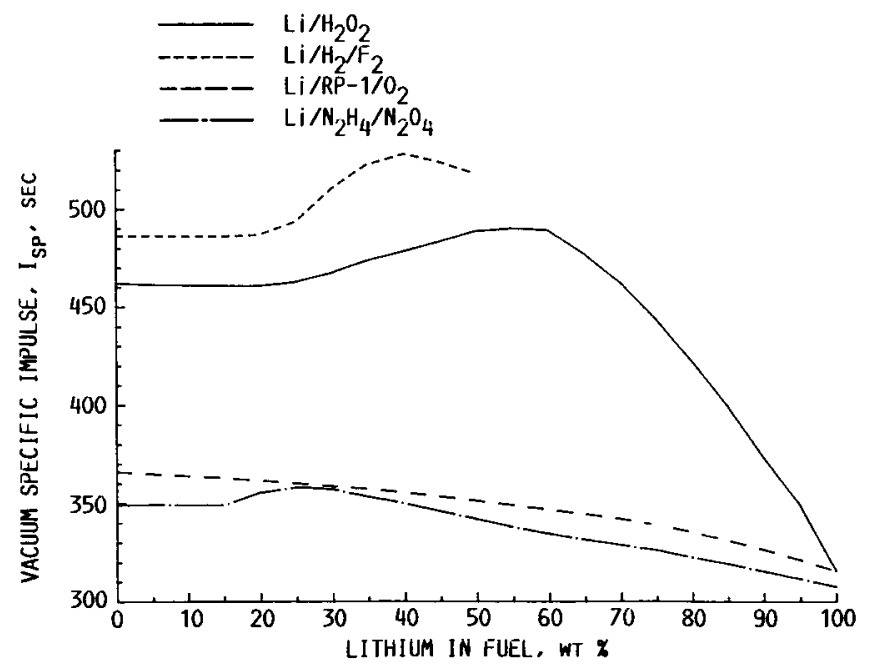

FIGURE 3. - PERFORMANCE OF LITHIUM AS A ROCKET PROPELLANT. $P_{C}, 6.895 \mathrm{MN} / \mathrm{M}^{2}$ (1000 PSIA): $\varepsilon, 60: 1$ : IDEAL EXPANSION. 


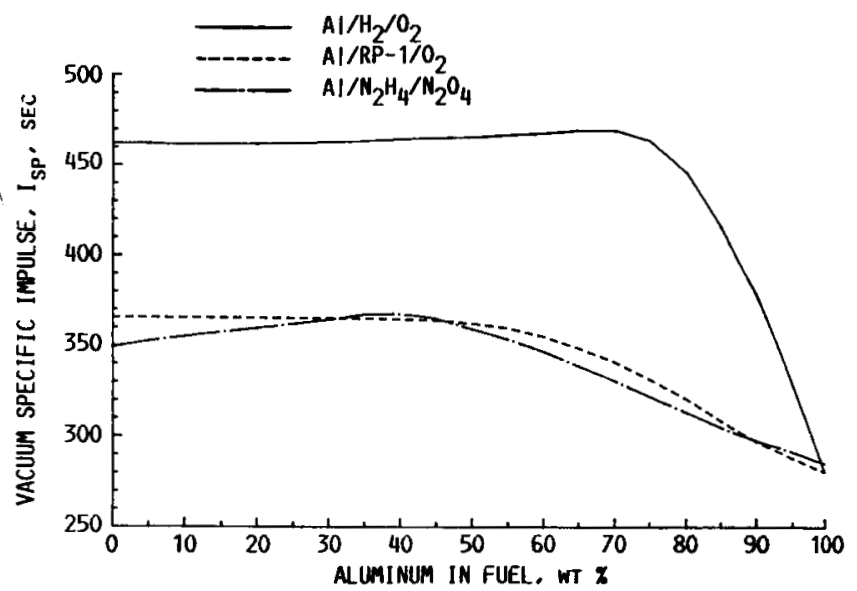

FIGURE 4. - PERFORMANCE OF ALUMINUM AS A ROCKET PROPELLANT. $P_{C}, 6.895 \mathrm{MN} / \mathrm{M}^{2}$ (1000 PSIA): $\varepsilon, 60: 1$ : IDEAL EXPANSION.

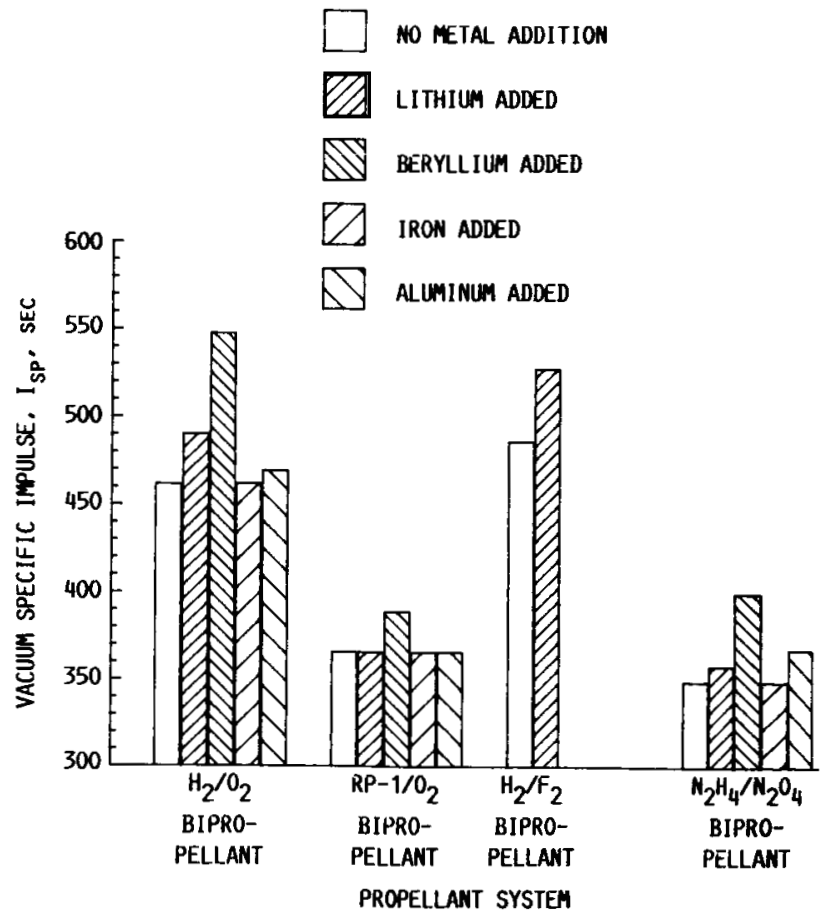

FIGURE 6. - ROCKET PERFORMANCE OF PROPELLANT SYSTEMS. $P_{C}, 6.895 \mathrm{MN} / \mathrm{M}^{2}$ ( 1000 PSIA) : $\varepsilon, 60: 1$; IDEAL EXPANSION.

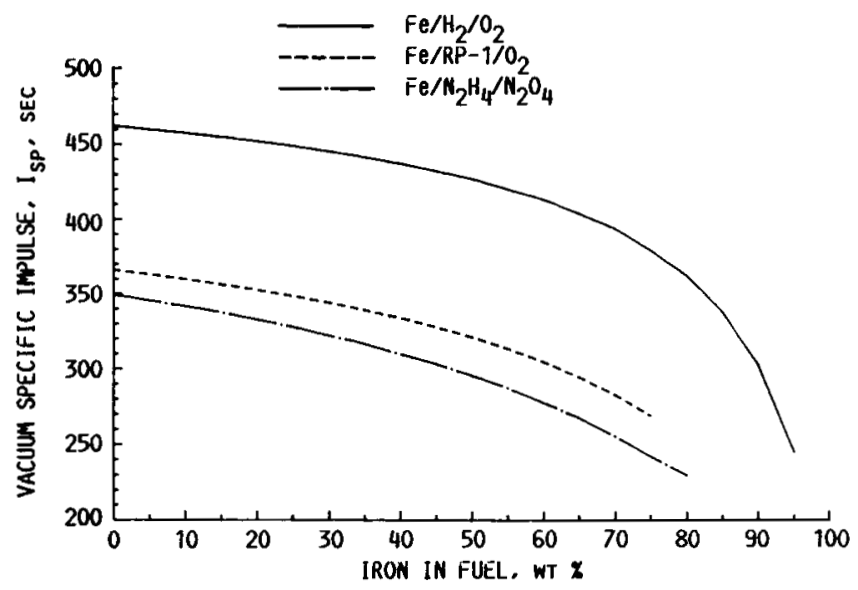

FIGURE 5. - PERFORMANCE OF IRON AS A ROCKET PROPELLANT. $P_{C}, 6.895 \mathrm{MN} / \mathrm{M}^{2}$ (1000 PSIA): $\varepsilon, 60: 1$; IDEAL EXPANSION.

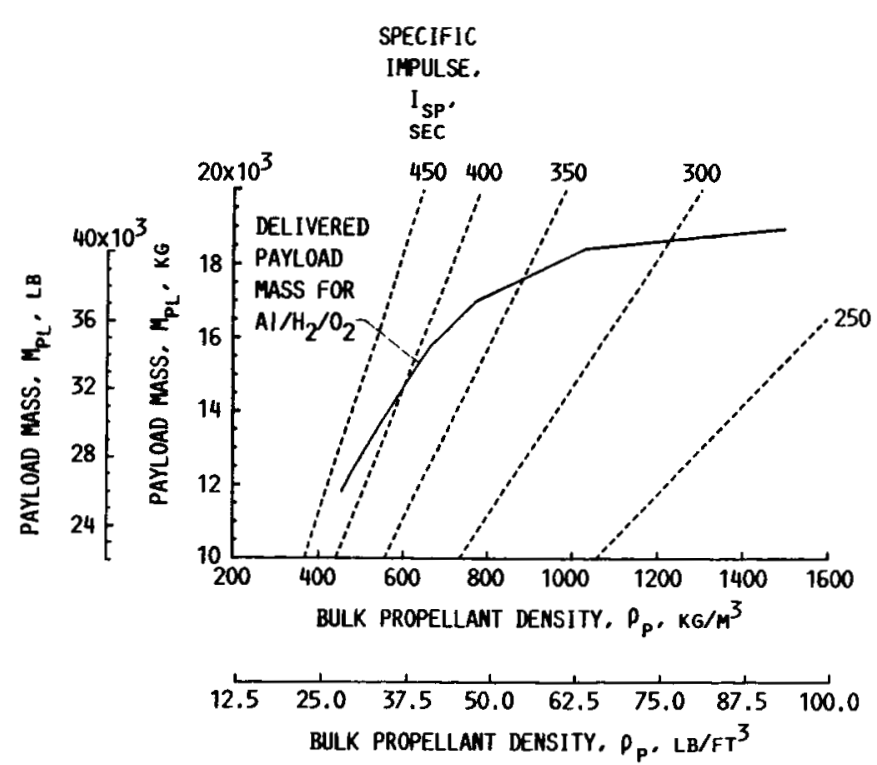

FIGURE 7. - EFFECT OF BULK PROPELLANT DENSITY AND SPECIFIC INPULSE ON DELIVERED PAYLOAD MASS. $\triangle \mathrm{V}, 4267.2 \mathrm{M} / \mathrm{SEC}$ $(14000 \mathrm{fT} / \mathrm{SEC}): M_{D R Y} \cdot 2761.6 \mathrm{KG}(6000 \mathrm{LB}) ; V_{P}, 56.63 \mathrm{~m}^{3}$ $\left(2000 \mathrm{FT}^{3}\right)$. 


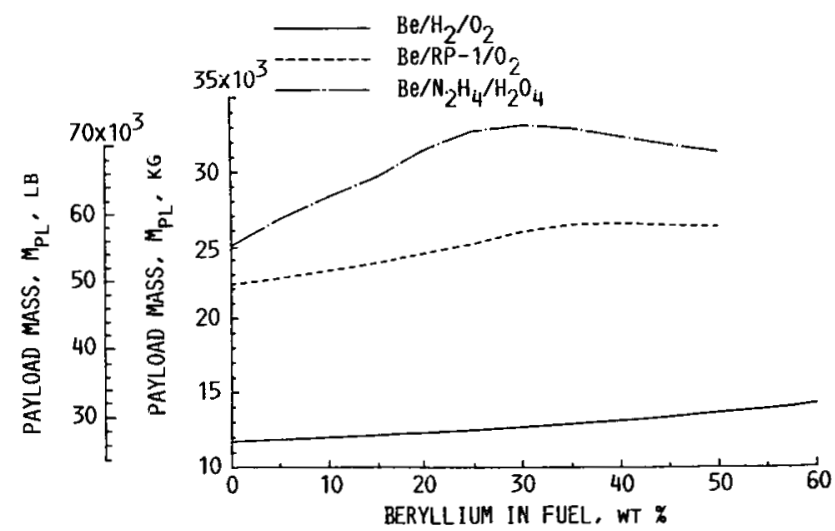

FIGURE 8. - PAYLOAD CAPABILITY OF BERYLLIUM TRIPROPELLANTS. $\Delta V, 4267.2 \mathrm{M} / \mathrm{SEC}(14000 \mathrm{FT} / \mathrm{SEC}) ; M_{\mathrm{DPY}} \cdot 2761.6 \mathrm{KG}$ $(6000 \mathrm{LB}): \mathrm{V}_{\mathrm{p}} .56 .63 \mathrm{~m}^{3}\left(2000 \mathrm{FT}^{3}\right)$.

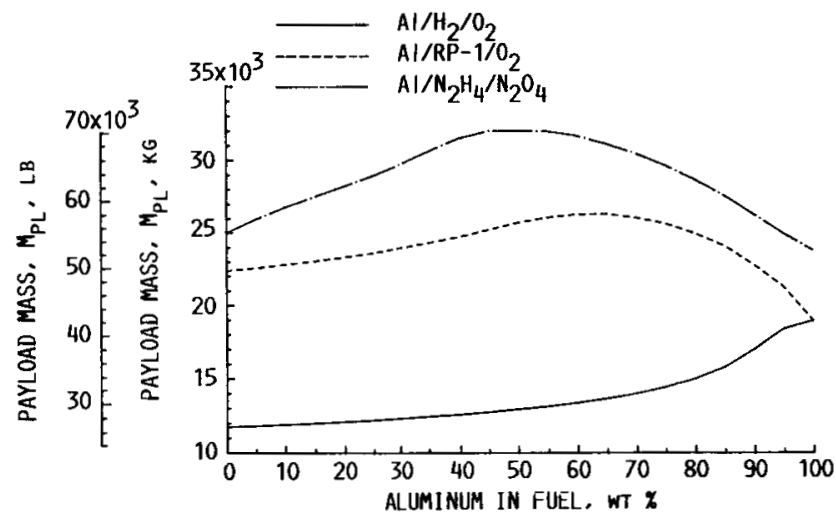

FIGURE 10. - PAYLOAD CAPABILITY OF ALUMINUM TRIPROPELLANTS. $\Delta V, 4267.2 \mathrm{M} / \mathrm{SEC}(14000 \mathrm{FT} / \mathrm{SEC}) ; M_{\mathrm{DRY}}=2761.6 \mathrm{kG}$ (6000 LB $): V_{p}, 56.63 \mathrm{~m}^{3}\left(2000 \mathrm{FT}^{3}\right)$.

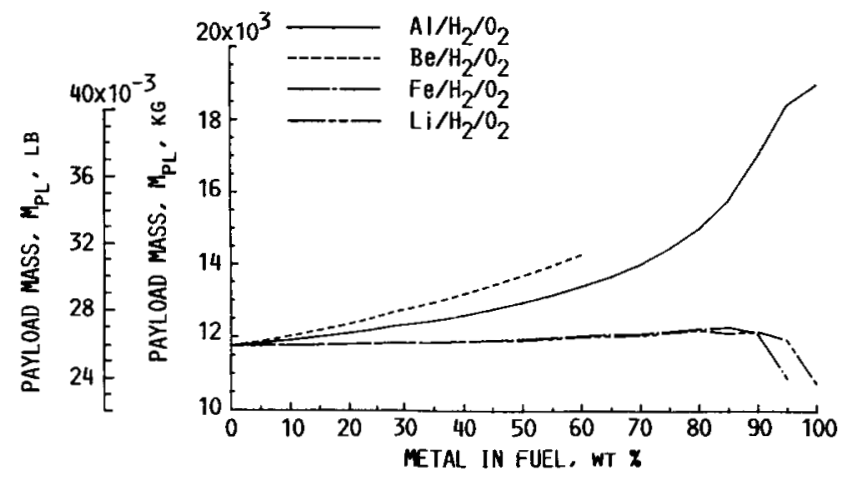

FIGURE 12. - VEHICLE PERFORMANCE OF METALS WITH $\mathrm{H}_{2} / \mathrm{O}_{2}$. $\Delta V .4267 .2 \mathrm{M} / \mathrm{SEC}(14000 \mathrm{FT} / \mathrm{SEC}) ; M_{\mathrm{DRY}} \cdot 2761.6 \mathrm{KG}$ $(6000 \mathrm{LB}): V_{p} \cdot 56.63 \mathrm{M}^{3}\left(2000 \mathrm{FT}^{3}\right)$.

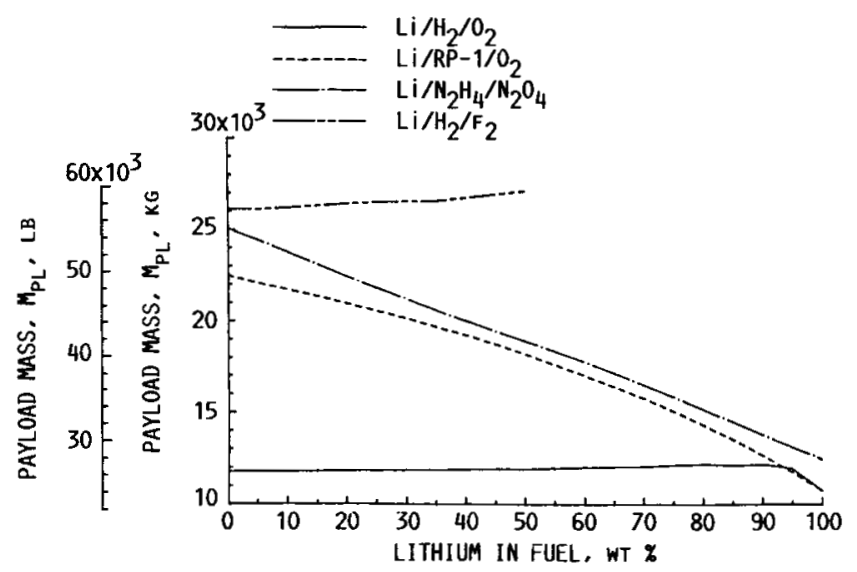

FIGURE 9. - PAYLOAD CAPABILITY OF LITHIUM TRIPROPELLANTS. $\Delta V, 4267.2 \mathrm{M} / \mathrm{SEC}(14000 \mathrm{FT} / \mathrm{SEC}) ; M_{\mathrm{DRY}}, 2761.6 \mathrm{KG}$ $(6000 \mathrm{LB}) ; \mathrm{V}_{\mathrm{p}}, 56.63 \mathrm{~m}^{3}\left(2000 \mathrm{FT}^{3}\right)$.

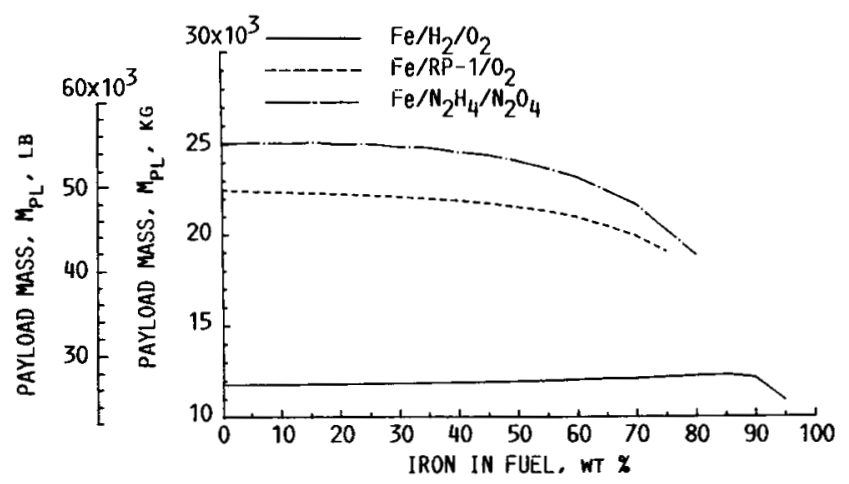

FIGURE 11. - PAYLOAD CAPABILITY OF IRON TRIPROPELLANTS. $\Delta V, 4267.2 \mathrm{M} / \mathrm{SEC}(14000 \mathrm{FT} / \mathrm{SEC}) ; \mathrm{M}_{\mathrm{DRY}}, 2761.6 \mathrm{KG}$ $(6000 \mathrm{LB}): V_{\mathrm{P}}, 56.63 \mathrm{~m}^{3}\left(2000 \mathrm{FT}^{3}\right)$.

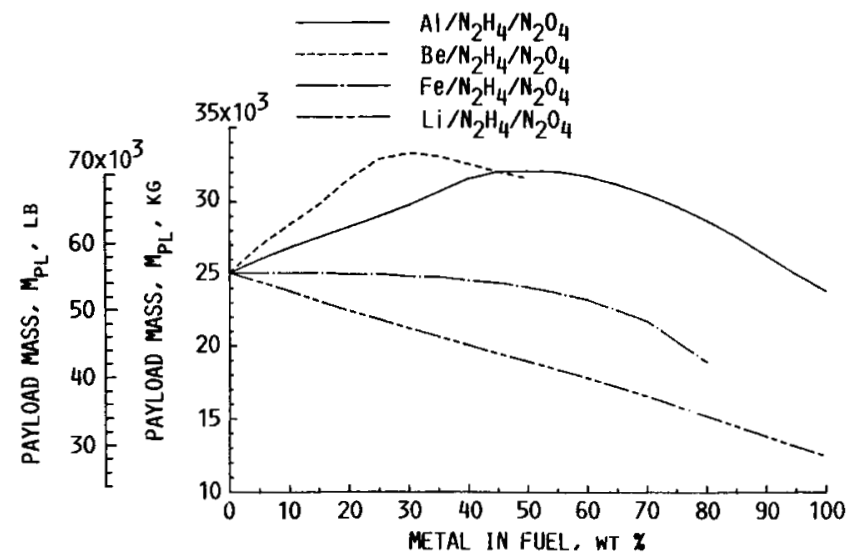

FIGURE 13. - VEHICLE PERFORMANCE OF METALS WITH $\mathrm{N}_{2} \mathrm{H}_{4} / \mathrm{N}_{2} \mathrm{O}_{4}$ $\Delta V, 4267.2 \mathrm{M} / \mathrm{SEC}(14000 \mathrm{FT} / \mathrm{SEC}) ; M_{\mathrm{DRY}} \cdot 2761.6 \mathrm{KG}$ (6000 LB $) ; V_{p} .56 .63 \mathrm{~m}^{3}\left(2000 \mathrm{FT}^{3}\right)$. 


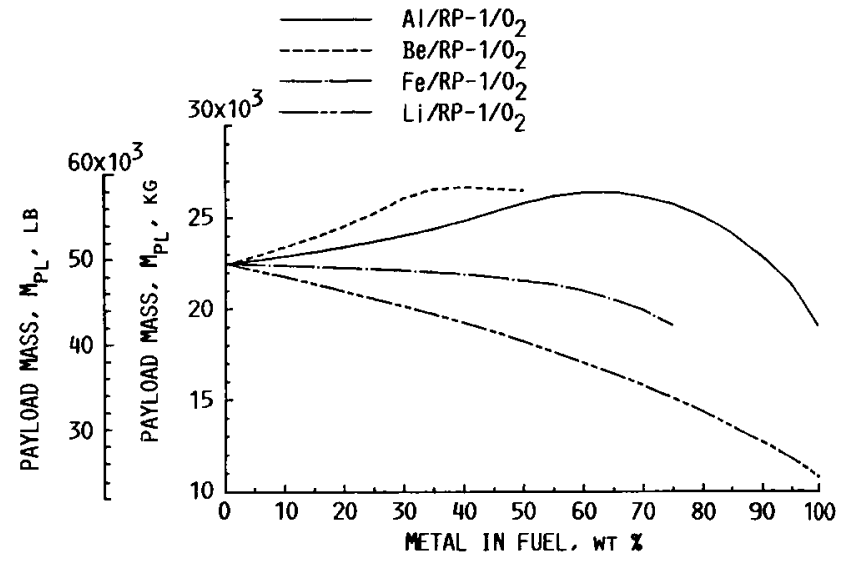

FIGURE 14. - VEHICLE PERFORMANCE OF METALS WITH RP- $1 / 0_{2}$. $\triangle V, 4267.2 \mathrm{M} / \mathrm{SEC}(14000 \mathrm{FT} / \mathrm{SEC}) ; M_{\text {DRY }}, 2761.6 \mathrm{kG}$ $(6000 \mathrm{LB}): V_{p}, 56.63 \mathrm{M}^{3}\left(2000 \mathrm{FT}^{3}\right)$.

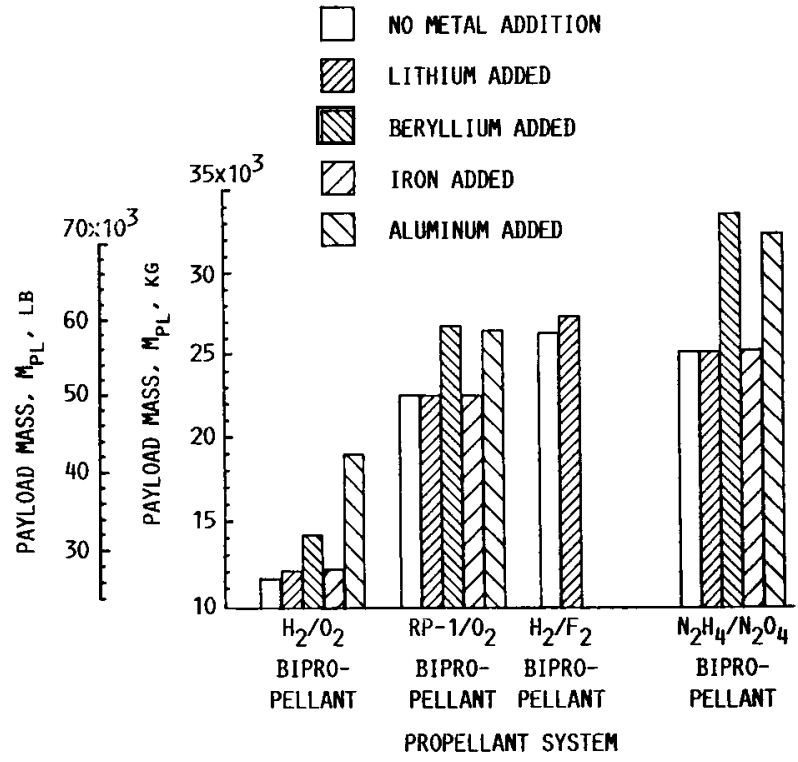

FIGURE 15. - VEHICLE PERFORMANCE OF PROPELLANT SYSTEMS. $\Delta V, 4267.2 \mathrm{M} / \mathrm{SEC}(14000 \mathrm{FT} / \mathrm{SEC}) ; \mathrm{M}_{\mathrm{DRY}}, 2761.6 \mathrm{kG}$ $(6000 \mathrm{LB}) ; V_{\mathrm{p}} \cdot 56.63 \mathrm{~m}^{3}\left(2000 \mathrm{FT}^{3}\right)$.

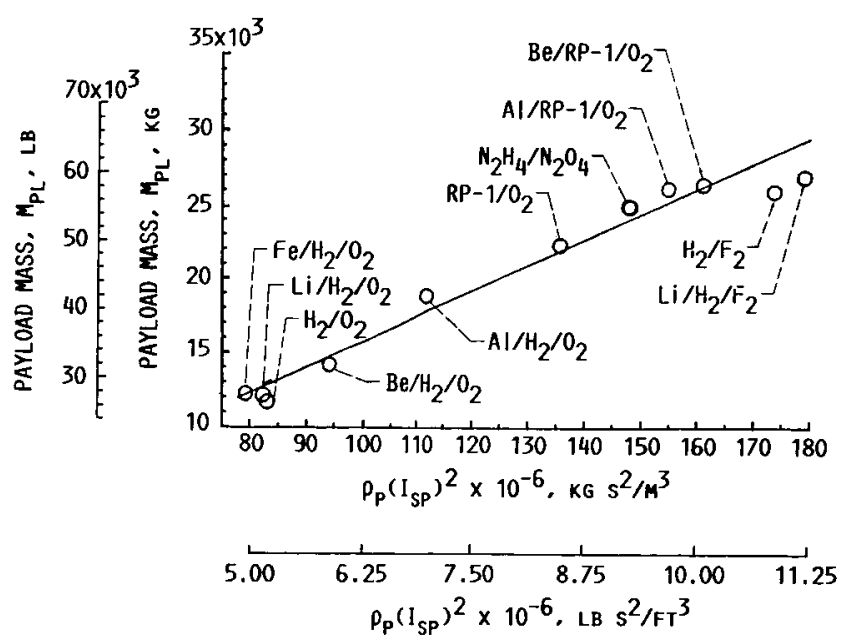

FIGURE 16. - RELATIVE PERFORMANCE OF PROPELLANT SYSTEMS BASED

ON $P_{P}\left(I_{S P}\right)^{2}$ PaRAMETER. $\triangle V, 4267.2 \mathrm{~m} / \mathrm{SEC}(14000 \mathrm{FT} / \mathrm{SEC})$ :

$M_{\text {DRY }}, 2761.6$ KG $(6000$ LB $) ; V_{p}, 56.63 \mathrm{M}^{3}\left(2000 \mathrm{FT}^{3}\right)$. 


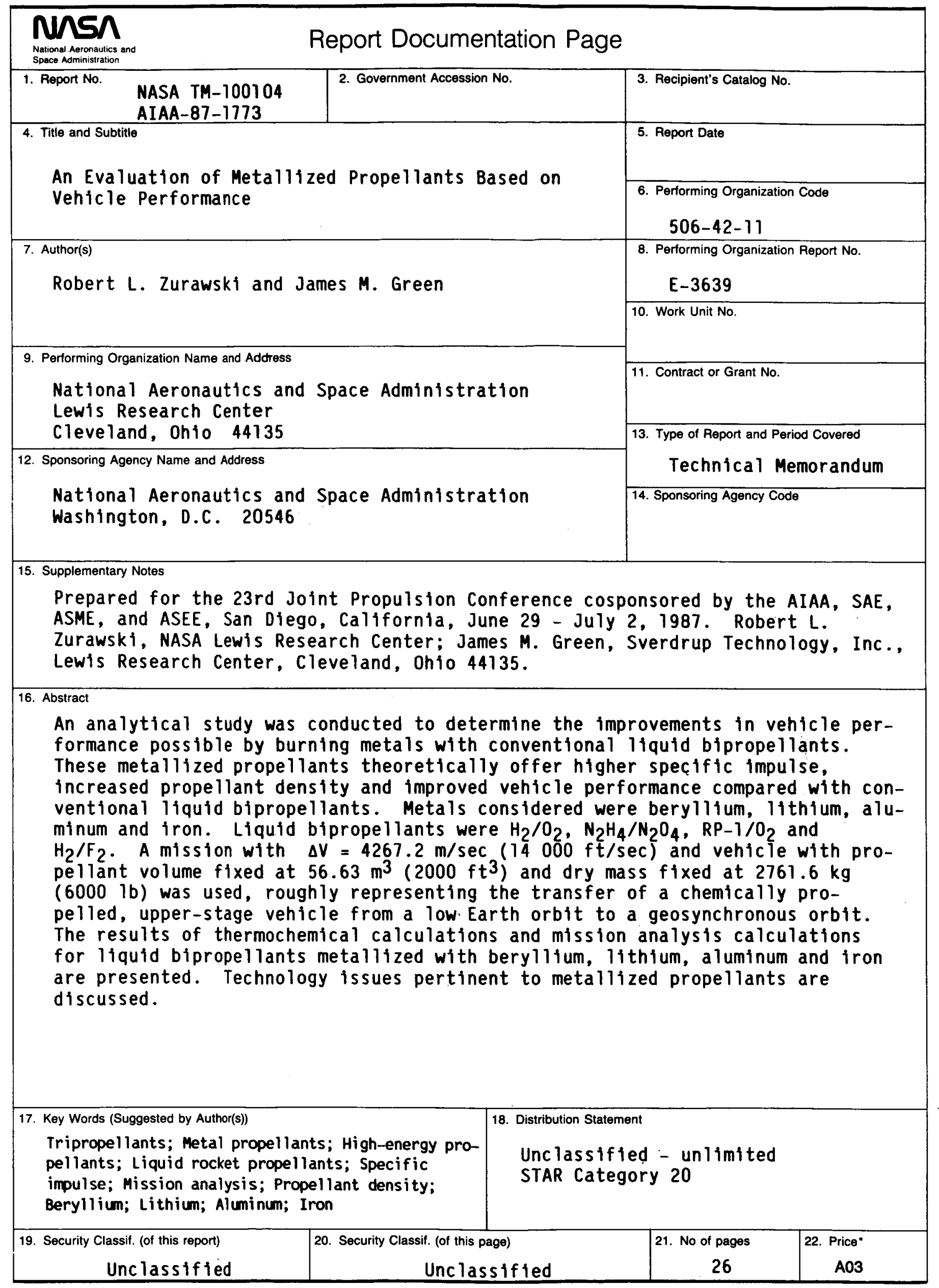

NASA FORM 1626 OCT $86 \quad$ *For sale by the National Technical Information Service, Springfield, Virginia 22161 